\title{
Coastal horse flies and deer flies (Diptera: Tabanidae)
}

\author{
Richard C. Axtell
}

\section{Contents}

15.1 Introduction

15.2 Morphology and anatomy

15.2.1 General diagnostic characteristics $\quad 416$

$\begin{array}{llr}15.3 & \text { Systematics } & 422\end{array}$

15.4 Biology $\quad 424$

$\begin{array}{lll}\text { 15.4.1 General life history } & 424\end{array}$

15.4.2 Life histories of saltmarsh species $\quad 425$

$\begin{array}{llr}15.4 .3 & \text { Seasonality } & 429\end{array}$

$\begin{array}{llr}15.4 .4 & \text { Food } & 429\end{array}$

$\begin{array}{ll}\text { 15.4.5 Parasites and predators } & 430\end{array}$

$\begin{array}{lll}15.5 & \text { Ecology and behaviour } & 431\end{array}$

15.5.1 Sampling methods 431

15.5.2 Larval distribution in marshes $\quad 432$

15.5.3 Adult movement and dispersal $\quad 433$

15.5.4 Role of tabanids in marsh ecosystems $\quad 434$

15.6 Economic importance $\quad 434$

15.7 Control $\quad 435$

15.7.1 Larval control $\quad 435$

$\begin{array}{lll}\text { 15.7.2 Adult control } & 435\end{array}$

$\begin{array}{ll}\text { References } & 436\end{array}$

\subsection{INTRODUCTION}

Members of the family Tabanidae are commonly called horse flies and deer flies. In the western hemisphere, horse flies are also called greenheads (especially in coastal areas). The majority of the species of horse flies are in the genus Tabanus; the majority of the deer flies in Chrysops. 
The tabanids include several more or less 'marine' insects since many species are found in coastal areas. Some species develop in the soil in saltmarshes, brackish pools and tidal overwash areas. A few species are found along beaches and seem to be associated with vegetative debris accumulating there. The majority of the tabanid species, however, develop in a variety of upland situations ranging from very wet to semi-dry (tree holes, rotting logs, margins of ponds, streams, swamps and drainage ditches).

Most tabanids are large, robust, strong fliers, vicious biters of man and animals, and, therefore, of economic importance. Their annoyance interferes with human activities and livestock culture. Disease transmission by tabanids occurs, frequently by mechanical means (with no development of the pathogen or parasite in the insect). It is likely that tabanids, along with other insects, are important in saltmarsh ecosystems but little is known on the subject. In this chapter only a brief synopsis of the family is given with further discussions confined to saltmarsh species of North America.

\subsection{MORPHOLOGY AND ANATOMY}

\subsubsection{General diagnostic characteristics}

The adults of the family Tabanidae are characterized by their large robust body (6-25 mm long). The deer flies are relatively slender and usually have patterned wings and mixed body colours of brown, yellow, orange and black. A typical coastal deer fly (Chrysops atlanticus Pechuman) is shown in Fig. 15.1. Horse flies (or greenhead flies) are usually more robust with clear or slightly shaded wings and some colouration on the body. A typical horse fly (Tabanus nigrovittatus Macquart) of saltmarshes is shown in Fig. 15.2. All tabanids have large compound eyes (Fig. 15.3) which are widely separated in the females, close together in the males and are more prominent (and often have colour bands) in the horse flies (Tabaninae) than in the other subfamilies. Between the eyes are various shaped areas (often protruding) referred to as the frontal calluses (basal and median). The mouthparts may be reduced in some groups or modified for feeding on plant nectar. Most female tabanids, however, have the mouthparts well developed for blood feeding and have stout maxillae and blade-like mandibles (Fig. 15.4). The males feed on nectar and their mouthparts are not capable of cutting the skin of a host. The antennae are distinctly 3 -segmented with annulations (false segmentation) on the terminal segment (flagellum) (Fig. 15.5). The wing venation is characteristic with branches of vein $\mathrm{R}_{4+5}$ diverging broadly so that they enclose the apex of the wing (2nd submarginal cell, cell $\mathrm{R}_{4}$ ) (Fig. 15.6 and 15.7).

The larvae (Fig. 15.8) and pupae (Fig. 15.9) of tabanids are usually various shades of brown and found in moist soil. For further detailed descriptions of the 


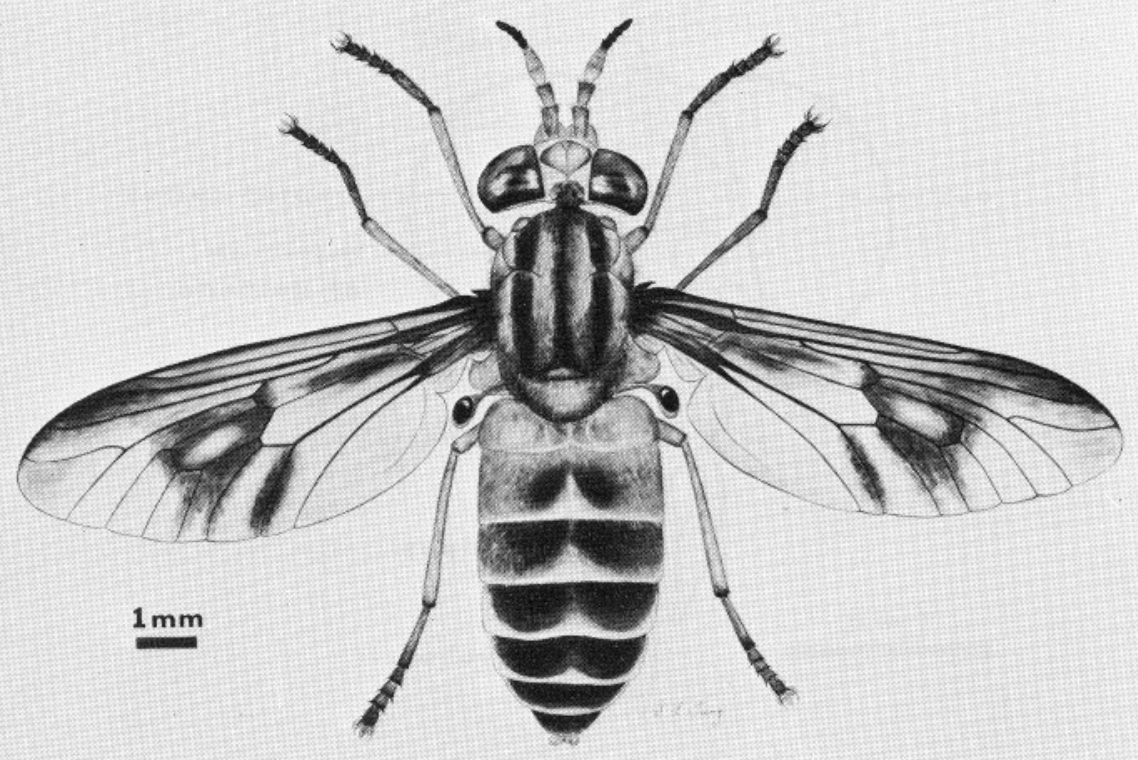

Fig. 15.1. A typical female deer fly, Chrysops atlanticus (Pechuman) (original drawing by S.L. Tung).

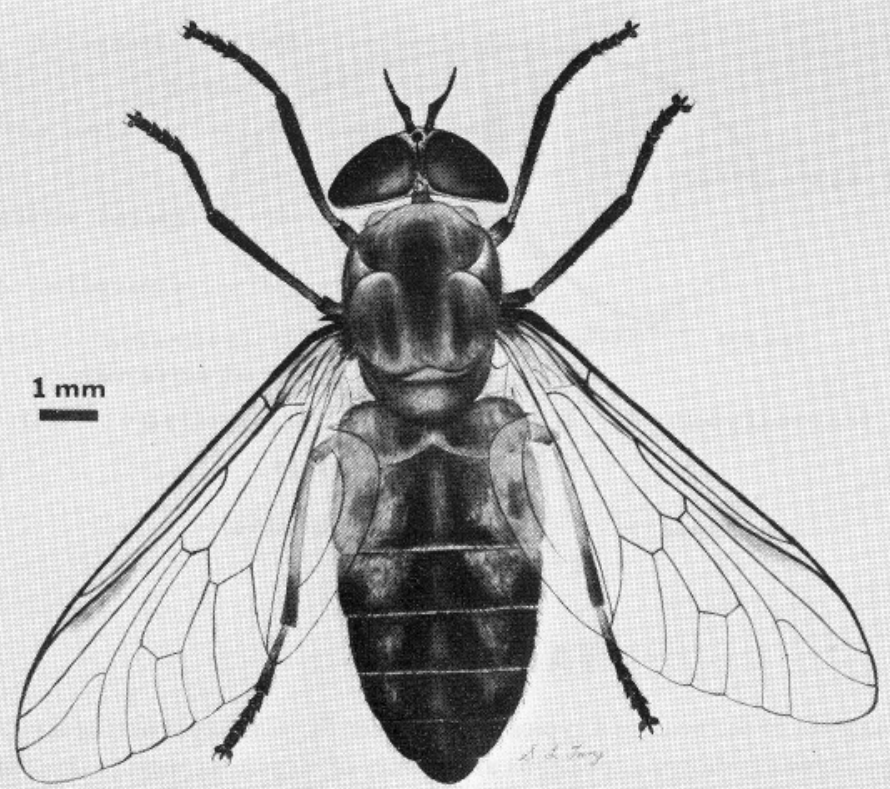

Fig. 15.2. A typical female horse fly (greenhead), Tabanus nigrovittatus (Macquart) (original drawing by S.L. Tung). 


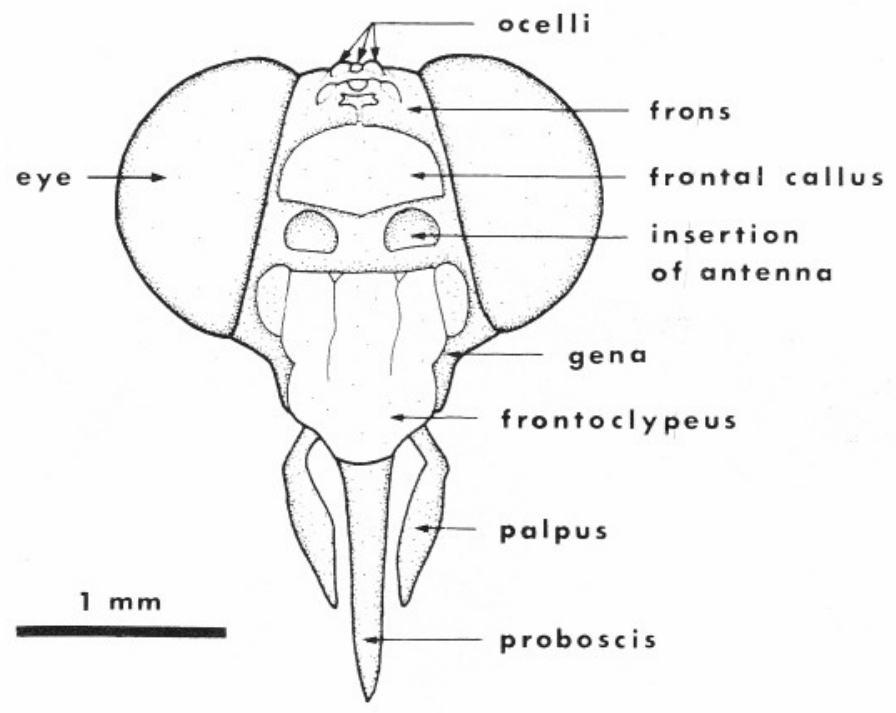

\section{CHRYSOPS}

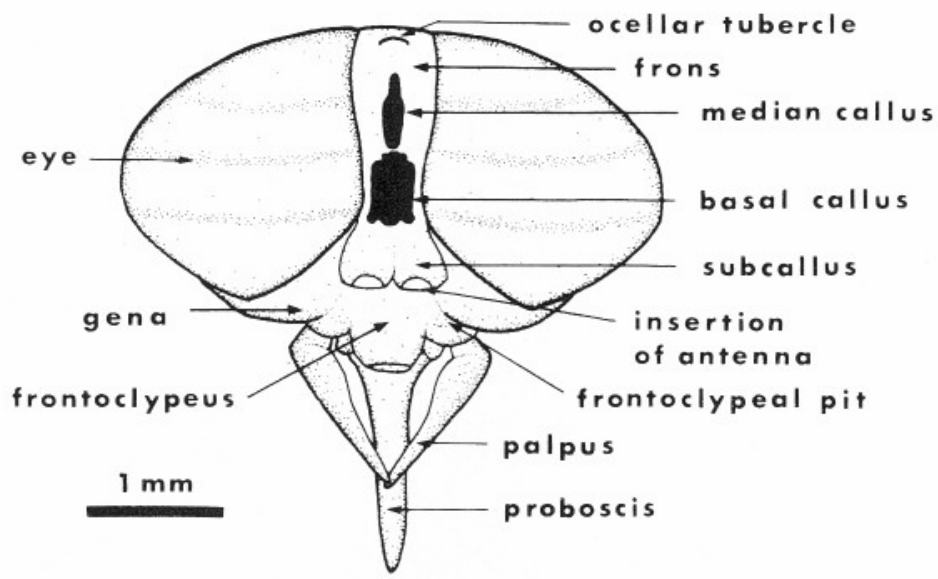

TABANUS

Fig. 15.3. Diagram of the head of a typical female deer fly (Chrysops) and of a typical female horse fly (Tabanus) showing locations and names of structures used in descriptions. 

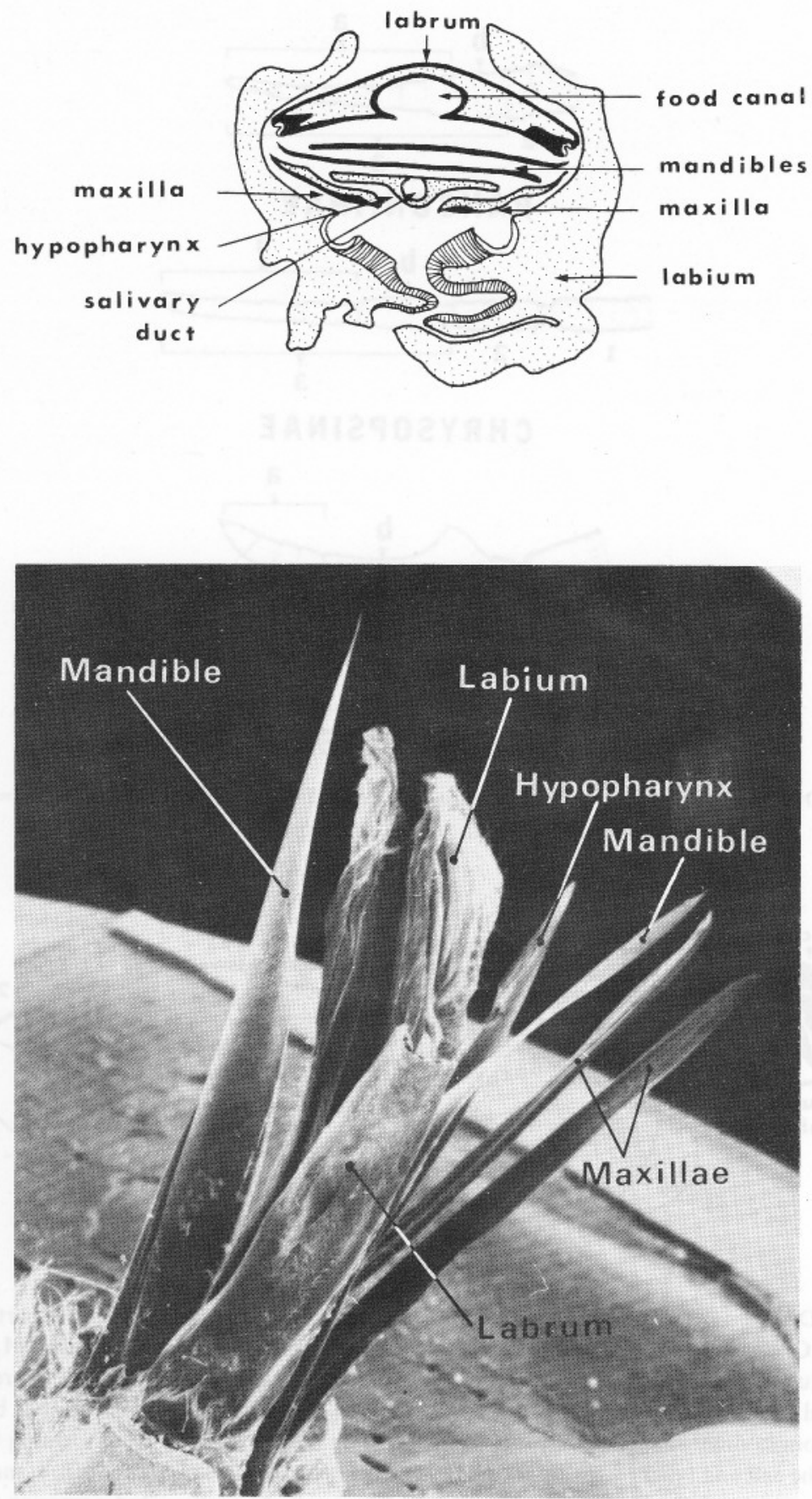

Fig. 15.4. (Above) Diagram of a cross-section of the mouthparts of a horse fly (Tabanus). (Below) SEM print of same. 


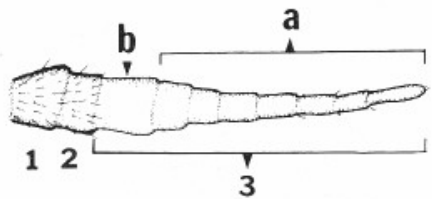

PANGONIINAE

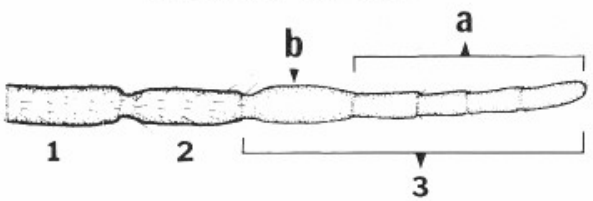

CHRYSOPSINAE

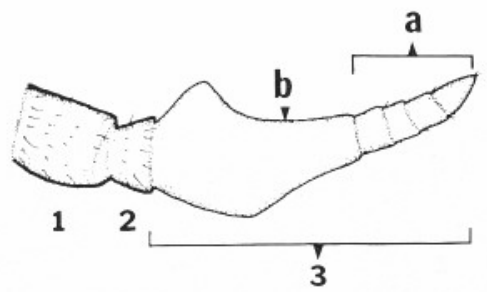

T ABANINAE

Fig. 15.5. Diagram of the shapes of the antennae in the subfamilies of Tabanidae. $1,2,3=$ segments; $\mathrm{a}=$ annuli; $\mathrm{b}=$ basal portion.

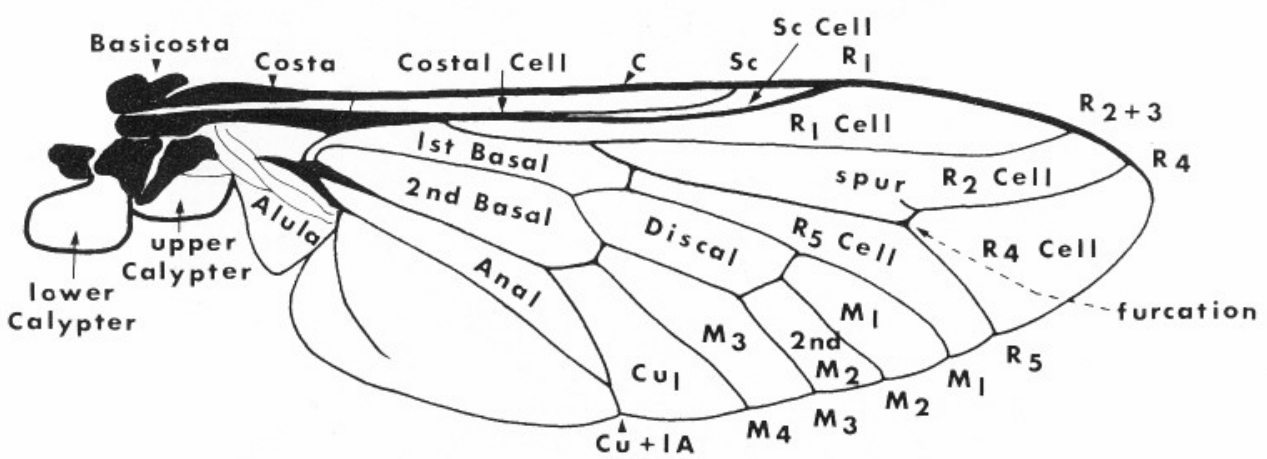

Fig. 15.6. Diagram of the wing of Tabanus showing names of veins, cells and basal parts. Veins are as follows: $\mathrm{C}=\operatorname{costa} ; \mathrm{S}_{\mathrm{c}}=\operatorname{subcosta} ; \mathrm{R}=\operatorname{radius}\left(\mathrm{R}_{1}, \mathrm{R}_{2+3}, \mathrm{R}_{4}, \mathrm{R}_{5}\right) ; \mathrm{M}=\operatorname{media}\left(\mathrm{M}_{1}, \mathrm{M}_{2}, \mathrm{M}_{3}\right)$; $\mathrm{Cu}=$ cubitus $\left(\mathrm{Cu}_{1}\right) ; \mathrm{A}=$ anal. Other names used by some workers for the veins are: $\mathrm{R}_{1}=1 \mathrm{st}$ longitudinal vein; $\mathrm{R}_{2+3}=2$ nd longitudinal vein; $\mathrm{R}_{4}=3 \mathrm{rd}$ longitudinal vein (upper branch) and $\mathrm{R}_{5}=3 \mathrm{rd}$ longitudinal vein (lower branch). The cells are named after the vein forming the anterior margin of the cell and labelled within the cells. Other names often used are $\mathrm{R}_{1}$ cell $=$ marginal cell; $\mathrm{R}_{2}$ cell = last submarginal cell $; \mathrm{R}_{5}$ cell $=1$ st posterior cell; $\mathrm{M}_{1}$ cell $=2$ nd posterior cell; 1 st $\mathrm{M}_{2}$ cell $=$ discal cell $; 2$ nd $\mathrm{M}_{1}$ cell $=3$ rd posterior cell $; \mathrm{M}_{3}$ cell $=4$ th posterior cell $; \mathrm{Cu}_{1}$ cell $=5$ th posterior cell; 1 st basal cell $=$ radial cell $; 2$ nd basal cell $=2$ nd medial cell. 


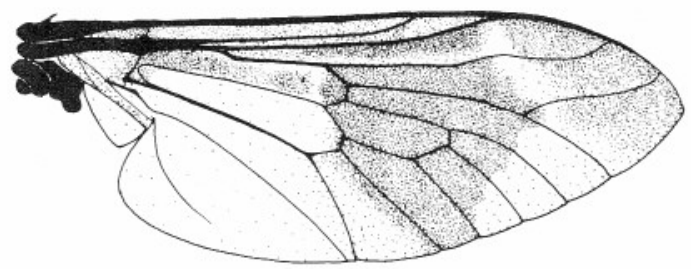

\section{C. fuliginosus}

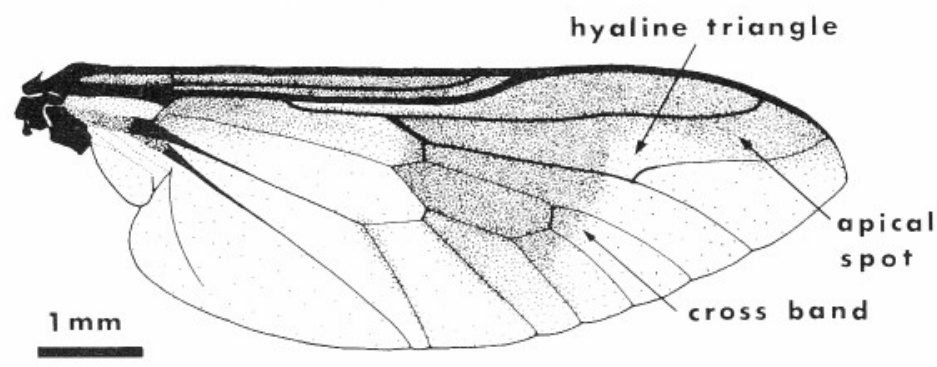

C. atlanticus

Fig. 15.7. Diagram of the wings of the saltmarsh deer flies Chrysops fuliginosus (Wiedemann) and Chrysops atlanticus (Pechuman) showing patterns of shading.

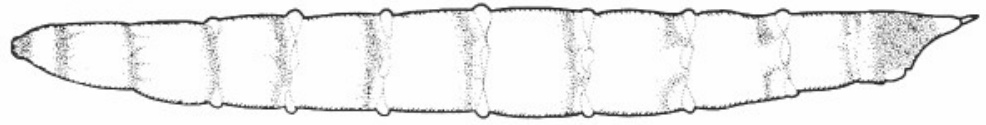

CHR Y SOPS

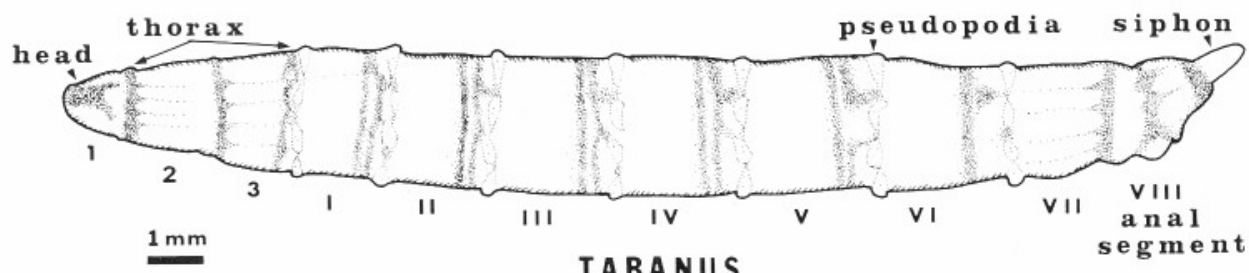

Fig. 15.8. Diagram of a typical larvae of a deer fly (Chrysops) and a horse fly (Tabanus) showing thoracic segments (1-3) and abdominal segments (I-VIII). Note the shape and characteristics of the siphon on the anal segment which aid in distinguishing between the two types of larvae. 


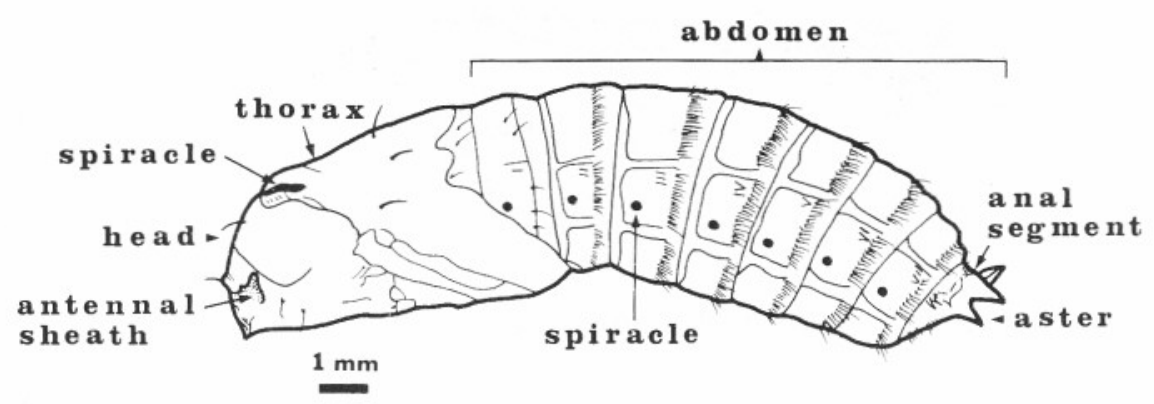

Fig. 15.9. Diagram of a pupa of Tabanidae.

internal and external morphology of the larvae and pupae refer to Teskey (1969) as well as the more specific works by Cameron (1934), El-Ziady and Hefnawy (1970) and Stammer (1924). Bonhag (1951) provides descriptions of the skeletomuscular systems of the adult stage.

\subsection{SYSTEMATICS}

There are at least 3500 species and more than 100 subspecies of Tabanidae recognized throughout the world (Fairchild, 1969a). These are grouped in 121 genera and 77 subgenera. The center of distribution of the recent species is considered to be in the tropics where most of the species occur.

The Family Tabanidae is generally divided into 3 subfamilies, Pangoniini, Chrysopsinae and Tabaninae, based mainly on the work of Mackerras (1954, 1955a, b) and his analysis of the genitalia (Philip, 1957). Each of these is divided into tribes.

Subfamily Pangoniinae: This is the most primitive and the adults are characterized as follows: Antennae short, tapering to a fine point, flagelium with $6-8$ subsegments (basal one is largest) (Fig. 15.5); ocelli usually well developed; hind tibia nearly always with paired apical spurs.

Subfamily Chrysopsinae: Adults are characterized as follows: Antennae short or long and not subulate with 2nd antennal segment (pedicel) nearly as iong as the first (scape) and flagellum of 3rd segment with usually 4 or fewer subsegments marked by faint annulations (Fig. 15.5); ocelli well developed; frontal callus well developed; hind tibia with paired apical spurs.

Subfamily Tabaninae: Adults are characterized as follows: Antennae sometimes similar to the Chrysopsinae but usually with shorter flagellum with very faint 
annulations ( 3 or 4 ) and often a dorsal lobe or projection is present on the basal part of the 3rd segment (Fig. 15.5); ocelli usually absent or very poorly developed; frontal calli well developed, hind tibia never with apical spurs.

These subfamilies and tribes are further characterized by other anatomical characters which are not practical for use in routine identifications, but they provide valuable insight into the phylogeny and evolution of the Tabanidae (Philip and Coscoran, 1971; Terteryan, 1973).

The various tribes are listed in Table 15.1. Only genera with marine species are discussed.

Table 15.1

List of coastal and saltmarsh Tabanidae.

Subfamily Pangoniinae -4 tribes.

Tribe Pangoniini - 13 major genera. There are no Ethiopian and Oriental genera. These are primitive Tabanidae which do not suck blood. Adults of many species have been collected in coastal areas but the larval habitats are mostly unknown.

Tribe Scionini - 6 major genera, no known marine species.

Tribe Philolochini - 1 major genus, no known marine species.

Tribe Scepsidini - 3 major genera. Scepsis Walker, collected mostly in Brazil, usually along white sand beaches; Adersia Austen and Braunsiomyia Bequaert, collected mostly in South Africa and often from seaweed on the beach. All have reduced mouthparts and are probably nonbiting.

Subfamily Chrysopsinae -3 tribes.

Tribe Bouvieromyiini - 4 major genera, no known marine species.

Tribe Chrysopsini - 2 major genera. Chrysops Meigen (worldwide) and Silvius Meigen (Palaearctic, Nearctic, Oriental). Chrysops is a large important genera with more than 270 species and many subspecies and forms. Fairchild (1971) lists 68 species for the Americas south of the United States and Philip (1965) lists 75 species for America north of Mexico. Although studies are limited, many species are associated with coastal habitats with some either known to be or suspected of breeding in the marshes. C. fuliginosus Wiedemann and C. atlanticus Pechuman, are major coastal species of North America. C. italiais Meigen is a common coastal species of southern Europe.

Tribe Rhinomyzini - 4 major genera, no known marine species.

Subfamily Tabaninae -3 tribes.

Tribe Diachlorini - There are a very large number of genera and species with the majority found in the Neotropical region. Some species of Diachlorus Osten Sacken are found in coastal habitats perhaps associated with marshes. Some species of Stenotabanus Lutz are coastal and adapted for living in beach environments. Chlorotabanus Lutz inicludes some pale yellowgreen forms often found in coastal environments.

Tribe Haematopotini - 2 major genera, no known marine species.

Tribe Tabanini - 8 major genera. The genus Tabanus Linnaeus is worldwide, with 94 species in North America north of Mexico, 139 species in Americas south of the U.S. and 49 species in Europe. Tabanus nigrovittatus Macquart and T. lineola Fabricius are the common salt marsh horse flies or greenheads of North America. Hybomitra Enderlein includes species often found in coastal environments. 
It is not practical to present a key to marine genera or species due to the limited information available on the habitats of the immature stages of most species. In eastern North America adults of as many as 40 or more species may be collected in a particular coastal area, but many have immature stages in upland sites (freshwater pools, stream beds, swamps, etc.) (Thompson, 1970, 1971b, 1972). Only few species are known to have larval stages in coastal marshes or brackish coastal waters.

The species which are most frequently encountered as adults and also breed in coastal saltmarshes of North America are Tabanus nigrovittatus (Macquart), T. lineola (Fabricius), Chrysops fuliginosus (Wiedemann) and C. atlanticus (Pechuman) (Bailey, 1947; Hansens, 1952; Jamnback and Wall, 1959; Rockel and Hansens, 1970a, b; Thompson, 1973; Axtell, 1974; Dukes et al., 1974a, b). T. nigrovittatus and T. quinquevittatus Wiedemann form a complex with five other closely related species whose members have often been misidentified (Thompson and Pechuman, 1970; Matthysse et al., 1974). T. quinquevittatus is sometimes collected in coastal areas but is not considered to be a saltmarsh breeder. Other species whose larvae have been occasionally found in saltmarshes or nearby brackish pools are listed by MacCreary (1940), Teskey (1969) and Tidwell (1973). Adults of a variety of other species are also often collected in small numbers in traps in or near saltmarshes.

For further and more detailed taxonomic information the reader should refer to recent catalogs of the Tabanidae with extensive literature references on species descriptions by Fairchild (1971) and Philip (1965, 1966). For larval and pupal stages, there exist several major publications which provide further information on morphology, keys to genera and species, and extensive literature references: (Hennig, 1952; Teskey, 1969; Goodwin, 1972, 1973a,b,c; Tidwell and Tidwell, 1973; Goodwin and Murdock, 1974; Tidwell, 1973). Regional publications which contain extensive literature references, illustrations and descriptions of adults are: (Oldroyd, 1952, 1954, 1957, 1969; Philip, 1954, 1955; Mackerras, 1956a,b, 1971, 1972; LeClercq, 1960, 1967; Takahasi, 1962; Fairchild, 1969b; Olsufjev, 1969a,b; Chvála et al., 1972; Carrasco, 1972; Pino et al., 1973; Pernot-Visentin and Beaucournu-Saguez, 1974). Other publications cover biology and adult identifications for Tabanidae of the Atlantic and Gulf coast regions of North America (MacCreary, 1940; Jamnbach and Wall, 1959; Jones and Anthony, 1964; Thompson, 1967, 1971a; Pechuman, 1972, 1973; Tidwell, 1973; Ezell et al., 1974).

\subsection{BIOLOGY}

\subsubsection{General life history}

All tabanids have the same basic life history (Jones and Anthony, 1964). The adult female lays eggs on vegetation close to moist soil suitable for larval develop- 
ment. They may be laid on stems or leaves of marsh grasses, emergent vegetation in and around a pond or pool, leaves of trees or shrubs overhanging water and occasionally on stones, sticks and debris (Knudsen and Rees, 1967; Tidwell and Hays, 1971; Foster et al., 1973). The eggs (1-3 mm long) are creamy white when laid but soon darken to shiny or brownish black. They are laid in masses of $100-800$ and arranged in a single layer, as in most Chrysopsini, or in several layers (usually two), as in Tabanini. The eggs hatch in a few hours; the first instar larvae enter the wet soil and complete development there. The larvae of most species require high moisture level and survive long periods submerged in water. Larval development includes several molts (usually 6-10) over a long period (several months to two years). The last instar larva migrates to or near the surface of the soil to pupate. The pupal stage may last for a few days or as long as 2-3 weeks depending on the species and the temperature. The adult emerges from the pupal case through a dorsal slit and, after a few hours of drying and hardening, is capable of sustained flight. Generally the males will emerge a little before the females. Mating may take place soon after emergence or later when the opportunity arises (Bailey, 1948a; Blickle, 1959; Catts and Olkowski, 1972). The diploid chromosome number ranges from 8 to 18 (Boyes and Wilkes, 1972).

In many species a blood-meal is needed for development of each batch of eggs and a female may lay two or three batches of eggs in a lifetime. However, several species have been shown to be autogenous, capable of producing an initial batch of eggs without a blood-meal (Rockel, 1969a; Anderson, 1971; Watanabe and Kamimura, 1971a; Thomas, 1972, 1973; Boseler and Hansens, 1974). Autogenous species apparently emerge in the marsh, remain there to mate and lay a single batch of eggs. They will then seek a vertebrate host for a blood-meal and return to the marsh to lay a second batch of eggs.

Generally, different species of tabanids emerge in discrete periods of the year, often with a single peak of abundance. In temperate regions, they overwinter in the larval stage. Owing to the long larval development period, the adults are usually derived from eggs laid a year, or even two years previously.

Data on life histories of tabanids are limited due to the extreme difficulty in maintaining these flies in the laboratory. Large larvae can often be held singly for pupation and adult emergence in vials of natural media or glass beads (Roberts, 1966), but rearing from egg to adult is rare and no laboratory colony has yet been achieved for any species.

\subsubsection{Life histories of saltmarsh species}

The four major North American saltmarsh species have been studied extensively but significant gaps still exist in our knowledge of their life histories. This, of course, reflects the difficulties in working these flies. 
(a) Tabanus nigrovittatus According to Jamnback and Wall (1959) this species deposits an egg mass ( $7.28 \mathrm{~mm}$ long and $3.4 \mathrm{~mm}$ wide) on Spartina alterniflora Loiseleur (smooth cordgrass) about $30 \mathrm{~cm}$ above the marsh sod where the plant blade is $5-6 \mathrm{~mm}$ wide; the mass is light brown and made up of two tiers. Individual eggs are $1.8 \mathrm{~mm}$ long and $0.38 \mathrm{~mm}$ wide at the widest point. Other researchers have had little or no success in finding T. nigrovittatus egg masses in the marshes even in the presence of high populations of adults. Consequently, there is considerable uncertainty about where the egg masses are laid and their appearance. Perhaps the egg masses are laid too low on the plants to be easily found, or perhaps they hatch quickly and the mass falls apart quickly. In any case, the larvae apparently hatch in a few hours and drop to the soil where development takes place. The duration of larval development and the number of moults has not been determined, but from the pattern of adult populations and from the yearly peak of large larvae and pupae recovered from soil samples, it apparently takes 9-10 months for the larvae to complete their moults. It is possible that some individuals take longer, even waiting for the second year, to pupate. Larvae are commonly collected from mud in areas of Spartina (Dukes et al., 1974a,b). The mature larva is about $24 \mathrm{~mm}$ long, pale amber colour with faint light brown rings on the abdomen and dark pattern of the anal segment. The pupa is about $13-18 \mathrm{~mm}$ long with head and thorax dark brown and abdomen yellowish brown. The larva and pupa are shown in Fig. 15.10 and described by Teskey (1969).

(b) Tabanus lineola Unlike the other three major saltmarsh species, the larval stage of this species is found in freshwater as well as in the saltmarshes. The adults of the freshwater forms tend to be darker than the yellowish saltmarsh forms (Teskey, 1969). The biology of the saltmarsh form has been described by Orminati and Hansens (1974) who found the eggs mainly on the tips of the blades of Spartina alterniflora and occasionally on another salt grass, Distichlis spicata (L.) Greene. The two-tiered egg masses (Fig. 15.11) are long and narrow (14-15 mm long and 1-2 mm wide), and contain an average of 208 eggs (27-416). Each egg is $1.5-1.7 \mathrm{~mm}$ long, $0.25 \mathrm{~mm}$ wide and dark grey when a few hours old. The eggs hatch in 4-5 days and the first-instar larvae drop, often in groups, to the soil surface. In the laboratory, larvae developed through 8-10 instars, taking about 200 days before pupating. Males on the average undergo one fewer moult than females. The pupal stage lasts 7-16 days. Development in the field may take a longer time.

(c) Chrysops fuliginosus The eggs of this species have not been found in the field but adult females have been induced to lay eggs in containers where they produced irregular egg masses with individual brown eggs about $1.1 \mathrm{~mm}$ long and $0.3 \mathrm{~mm}$ wide (Jamnback and Wall, 1959). Presumably the eggs are laid on saltmarsh grasses and rapidly hatch. Larvae are commonly collected in the mud 


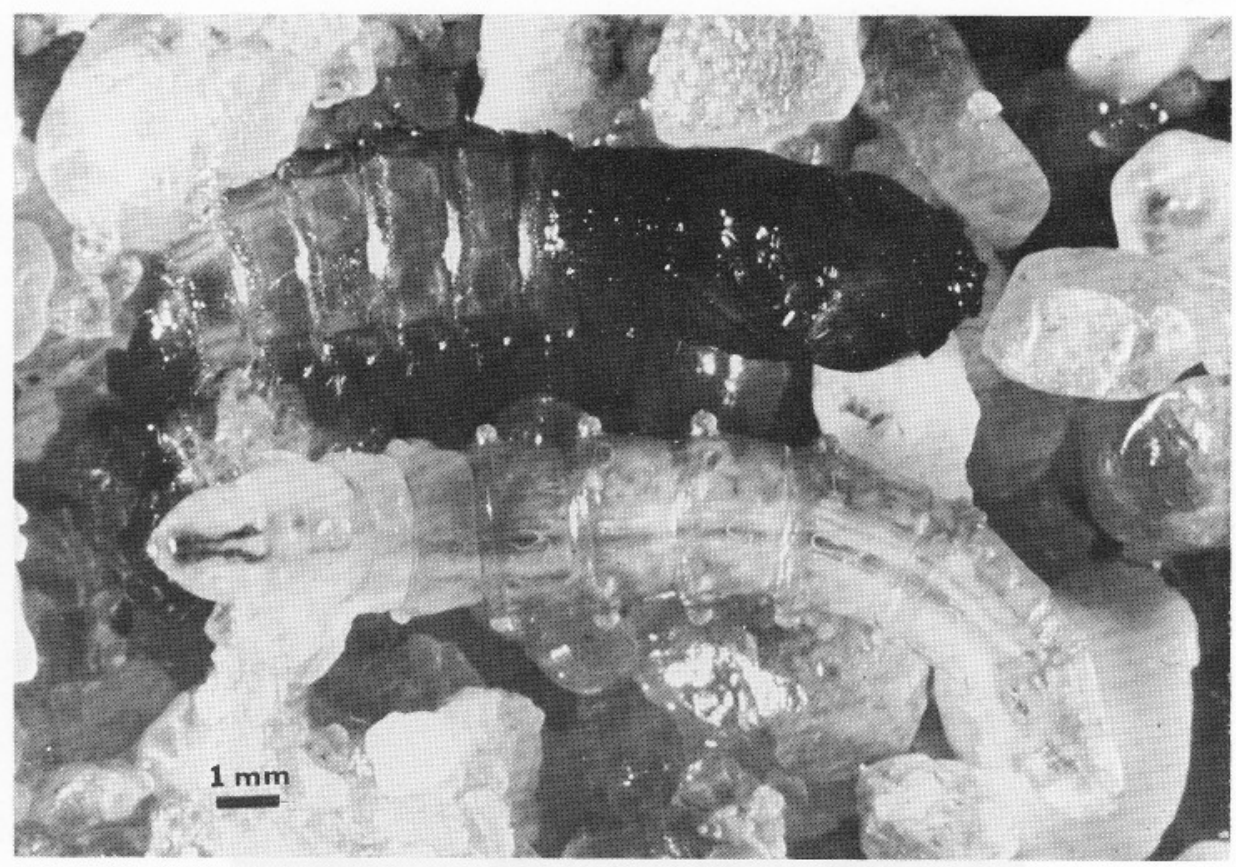

Fig. 15.10. Larva (lower) and pupa (upper) of Tabanus nigrovittatus. (Photo courtesy of E. Hansens, Rutgers University.)

in areas of Spartina alterniflora (Dukes et al., 1974a,b). The number of moults and period for larval development have not been reported. It probably takes about one year in the field since there is a single peak period of adults each year which lasts for only about a month. The mature larva (14 mm long) pupates in the upper portions of the marsh soil and adult emergence apparently occurs a few days later. The larvae and pupae have been described by Teskey (1969).

(d) Chrysops atlanticus Eggs of this species have not been adequately described and there are few larval collections. Jamnback and Wall (1959) found egg masses (13-32 $\mathrm{mm}$ long and $2.1 \mathrm{~mm}$ wide) on Spartina alterniflora about $30 \mathrm{~cm}$ above the sod in a single tier, with each egg measuring $1.5 \mathrm{~mm}$ long and $0.3 \mathrm{~mm}$ wide. Subsequent workers have searched for these egg masses with no success. The larva and pupa were described by Jamnback and Wall (1959) and Teskey (1969). Goodwin (1972) reared pupae from larvae collected from a shallow water area of a brackish pool ' 300 yards from the Atlantic Coast'. The period for larval development is not known, although it is likely to be about a year since a single peak of adult occurrence is found early each summer. With the abundance and common occurrence of this species along the Atlantic Coast of North America, it is surprising that so few larvae have been found or adults collected in emergence 


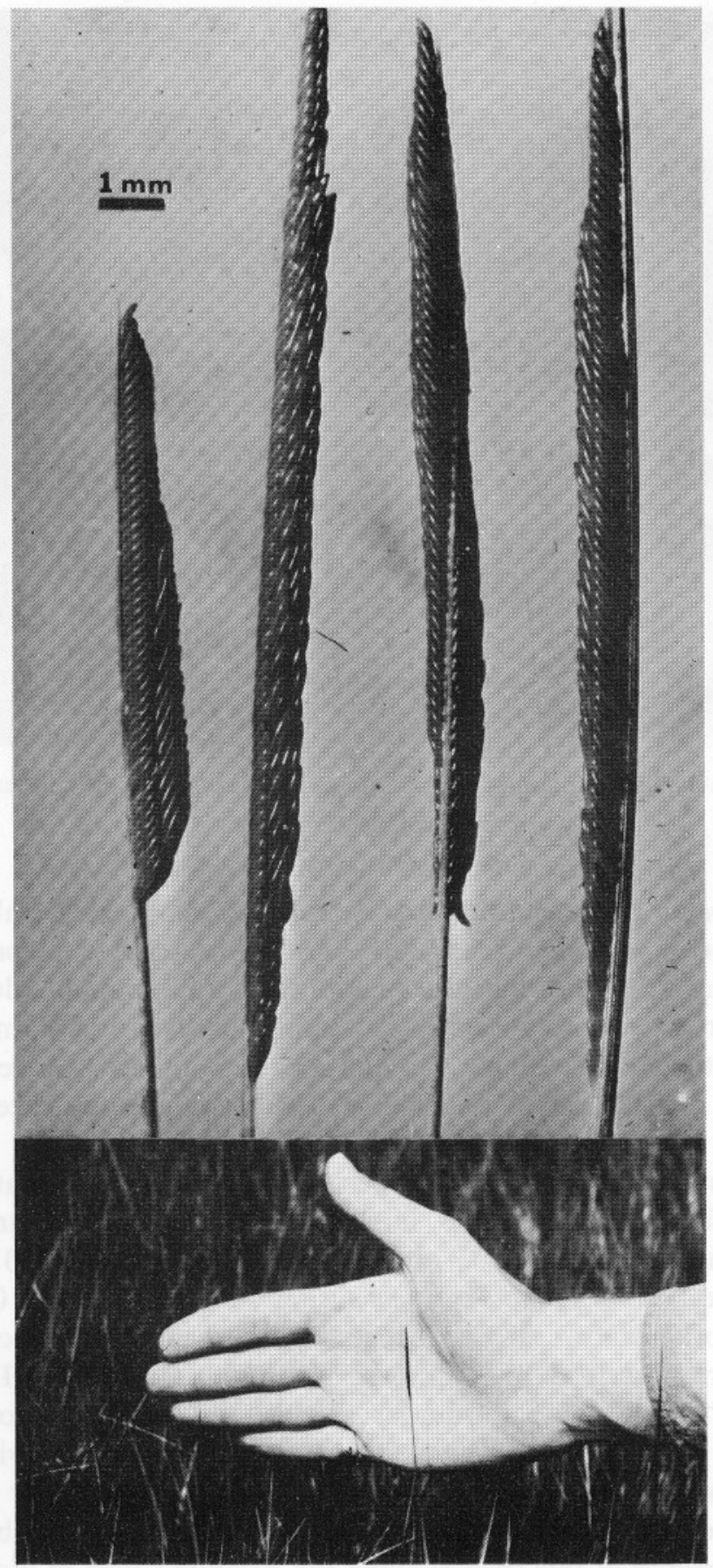

Fig. 15.11. Clusters of eggs of Tabanus lineola on blade of marsh grass, Spartina patens. (Photo courtesy of E. Hansens, Rutgers University.) 
traps. The few records available were mostly from Spartina alterniflora marshes (Rockel and Hansens, 1970; Dukes et al., 1974b) but the possibility of more upland breeding sites cannot be ruled out.

\subsubsection{Seasonality}

The seasonal abundance of adults of the four saltmarsh species, as well as many other coastal species, has been well documented in several locations by means of systematic trapping and netting. In the mid-Atlantic coastal area of the United States, Tabanus nigrovittatus is present from mid-May to late September with a peak of abundance in mid-June; T. lineola is present in low numbers from late May to late September with a peak in August and early September; Chrysops atlanticus is present from late April to late September with a peak in early June (sometimes a smaller peak in late August), and C.fuliginosus is present from early April to early June with a peak in early May. The patterns of population levels are much the same in other locations with adjustments, of course, for later and shorter periods of activity in the more northern coastal areas and for earlier and longer periods in the more southern areas. These have been well documented. (Hansens, 1952; Jamnback and Wall, 1959; Wall and Doane, 1960; Jones and Anthony, 1964; Anderson, 1971, 1973; Hansens and Robinson, 1973; Thompson, 1973; Matthysse et al., 1974; Dale and Axtell, 1975a.)

\subsubsection{Food}

Adult female tabanids are blood feeders and occasionally nectar feeders, while the males are nectar feeders (Anthony and Jones, 1964; Roberts, 1967). Consequently, mostly females are attracted to carbon dioxide and are collected in traps which are empirically designed to simulate a host. Only a few males are caught in such traps and they are more often collected by netting from shrubs and grasses especially during the flowering period (Pratt and Pratt, 1972). Sources of pollen in the gut of several tabanids, including T. nigrovittatus and T. lineola, have been analyzed by Wilson and Lieux (1972). Although blood feeding is mostly on mammals, occasional feeding of birds also occurs (Davies, 1959; Bennett, 1960; Wilson and Richardson, 1969). The behaviour, chemical stimulants and chemoreceptors associated with feeding have been investigated in some upland species (Crewe and Gordon, 1959; Dickerson and Lavoipierre, 1959; Lall and Davies, 1967, 1971; Hafez et al., 1970; Lall, 1970a,b,c).

Little is known about the food of the larval stages. They apparently feed on small invertebrates, micro-organisms and organic matter in the wet soil. Tabanus larvae have stout mouthparts and readily feed on small housefly larvae in the laboratory. They are cannibalistic and must be reared individually. Chrysops larvae are smaller and do not readily feed on insect larvae in the laboratory. 
They are usually not cannibalistic. In the saltmarshes, tabanid larvae have a variety of potential food sources including often a high density of Culicoides larvae.

\subsubsection{Parasites and predators}

A list of parasites and predators of tabanids in general can be found in Jenkins (1964) and a new list is in preparation by D.W. Anthony (personal communication). Egg parasites include the following Hymenoptera: Scelionidae (Telenomus), Mymaridae (Patasson) and Trichogrammatidae (Trichogramma). Telenomus emersoni (Girault) emerged from $14 \%$ of the egg masses of Tabanus lineola held by Orminati and Hansens (1974) and destroyed about $90 \%$ of the eggs in the parasitized masses. Telenomus tabanivorus (Ashmead) have been reported from other Tabanus egg masses and a closely related species of Telenomus from Chrysops egg masses (Jackson and Wilson, 1966; Dukes and Hays, 1971). Jones (1953) and Tashiro and Schwardt (1953) found high rates $(35-45 \%)$ of parasitism on Tabanus by Telenomus tabanivorus. Patasson sp. was reported by Philip (1931) from Chrysops. Trichogramma minutum (Riley) and Trichogramma semblidis (Aurivillus) have been reported mostly from upland Chrysops (Cameron, 1926; Philip, 1931; Tashiro and Schwardt, 1953).

Several genera of Tachinidae (Diptera) have been reported to parasitize tabanid larvae (Jones, 1953; Tashiro and Schwardt, 1953; James, 1963; Jones and Anthony, 1964; Soratt and Wolf, 1972). Other larval parasites include a nematode Bathymermis (James, 1963; Shamsuddin, 1966), a microsporidian Telohania tabani (Gingrich, 1965) and a Coelomomyces fungus (Dubitskii et al., 1974).

Trichopria tabanivora Fouts (Diapriidae), a hymenopteran pupal parasite, has been reported from T. nigrovittatus (Bailey, 1947) and T. lineola (Jones, 1953; Jones and Anthony, 1964). Another hymenopteran pupal parasite Diglochis occidentalis (Ashmead) (Pteromalidae) has been found in upland Chrysops (Cameron, 1926; Philip, 1931). Parasites of adult tabinids include nematodes (Gordius) according to Philip (1931) and various mites (Jones and Anthony, 1964).

Predation on tabanid eggs probably occurs more frequently than is realized since the egg masses are exposed. Larvae and adults of the coccinelid beetle Naemia seriata (Melsheimer) attack egg masses of $T$. lineola in the saltmarsh (Orminati and Hansens, 1974). Johnson and Hays (1973) reported several insects preying upon Chrysops egg masses, but concluded that predators probably were of little significance in the natural control of Tabanidae.

Several insects preying on adult tabanids have been reported including dragonflies (Odonata), wasps (Sphecidae) and robber flies (Asilidae), (Philip, 1931; Jones, 1953; Jones and Anthony, 1964; Roberts and Wilson, 1967).

Birds have frequently been reported as consuming tabanid larvae, pupae and 
adults, although this predation is probably insignificant (Philip, 1931). Jones and Anthony (1964) were unable to find tabanid larvae in the crops of insectivorous and marsh-inhabiting birds in Florida. Cattle egrets (Bubulcus ibis) may occasionally consume an adult tabanid although mostly other insects are eaten (Burns and Chapin, 1969; Jenni, 1969; Snoddy, 1969; Siegfried, 1971; Dinsmore, 1973; Fogarty and Hetrick, 1973).

Predators of Tabanidae are probably incidental and exert little effect on the population. Certain parasites, occasionally reported at high incidence levels, may be important population regulators and greater research effort is warranted.

\subsection{ECOLOGY AND BEHAVIOUR}

\subsubsection{Sampling methods}

Studies on the ecology and behavior of Tabanidae are subject to bias due to different sampling methods used. Many ecological studies on saltmarsh invertebrate fauna should have yielded useful information on Tabanidae, but the researchers did not use appropriate sampling methods (Davies and Gray, 1966; Cameron, 1972).

Collection of larval tabanids is time-consuming, laborious and often unproductive. Principal methods which have been used are digging with a hand towel, treatment of the soil with chemical larvicides, drying the soil samples (on outdoor racks or Berlese funnels or in Tullgren funnels equipped with incandescent bulbs) and washing the soil through a series of sieves (Bailey, 1948b; Hansens, 1956; Anthony, 1957; Wall and Jamnback, 1957; Teskey, 1962; James, 1963; Rockel and Hansens, 1970a; Thomas, 1971; Freemen and Hansens, 1972; Edwards et al., 1974).

Adult tabanids may be collected by netting from human or other animal hosts and this also gives a direct measure of the nuisance level. The time of day, however, can drastically affect the results. Sweep netting is often used in marsh ecology studies but is quite useless in catching the fast-moving tabanids. Traps of various types have been used and these differ in their species selectivity. These trapping methods include: sticky surfaces, Malaise traps, box traps, canopy traps and some systems involving use of decoys, carbon dioxide, ultraviolet as well as visible light (Bracken and Thorsteinson, 1965; Bracken et al., 1965; Smith et al., 1965; Thorsteinson et al., 1965, 1966; Wilson et al., 1966; DeFoliart and Morris, 1967; Easton et al., 1968; Wilson, 1968; Thompson, 1969; Catts, 1970; Granger, 1970; Roberts, 1970a,b, 1971, 1974; Hansens et al., 1971; Neys et al., 1971; Adkins et al., 1972; Blume et al., 1972; Knox and Hays, 1972; Watanabe and Kamimura, 1973; Anderson et al., 1974; Thompson and Gregg, 1974; Axtell et al., 1975). Suction traps (Service, 1973) and sticky balloons (Snoddy, 1970) have been used for sampling Chrysops. The efficiency and composition of the samples 
collected by different methods are rather variable. Ultraviolet light traps tend to collect larger numbers of males of saltmarsh T. lineola as well as some T. nigrovittatus and C. atlanticus (Morgan and Ubel, 1974); both Tabanus spp. are readily collected in box traps as well as in canopy traps. C. fuliginosus is poorly collected in the box traps but fairly well represented in canopy traps, while $C$. atlanticus is poorly collected by either type of trap. The sticky traps are on the whole fairly satisfactory for all four species of saltmarsh tabanids.

\subsubsection{Larval distribution in marshes}

Coastal saltmarshes vary in relative abundance and vigor of plants and tidal amplitudes. Consequently, it is not surprising that studies on Tabanidae from different marshes yield results which differ in details. However, a general pattern has emerged from studies in marshes along the Atlantic coast of the United States. Caution should be used in extrapolating these findings to other regions.

Generally these coastal saltmarshes inhabited by Tabanidae can be subdivided according to the degree and frequency of tidal flooding which is reflected in the type of vegetation (Adams, 1963; Hotchkiss, 1970; Cooper, 1974). Spartina alterniflora (Loiseleur) is found in areas usually flooded twice a day. At slightly higher elevations where there is less flooding and shorter durations of standing water, the marsh is usually covered by Spartina cynosuroides (L.) Roth (giant cordgrass), Spartina patens (Ait.) Muhl. (salt meadow grass), and Distichlis spicata (L.) Greene (salt grass). At higher elevations, flooded only during lunar tides, periods of high rainfall, etc., the dominant vegetation is Juncus roemerianus Scheele (black needlerush) or related species.

Larvae of the common saltmarsh tabanids, Tabanus nigrovittatus, T. lineola, Chrysops fuliginosus and a few $C$. atlanticus are most often recovered from soil collected in the regularly flooded areas of Spartina alterniflora. Progressively fewer larvae are found in areas with less flooding, and extremely few have been found in Juncus marshes. Such plant-tabanid associations are described and discussed by MacCreary (1940), Bailey (1947), Jamnback and Wall (1959), Freeman (1962), Rockel (1969b), Rockel and Hansens (1970a,b), Freeman and Hansens (1972), Dukes et al. (1974a,b).

Spartina alterniflora marshes are the major sources of tabanids. This sea grass has a tall form dominating along the sides of drainage ditches and a short form in the general expanse of coastal saltmarshes. This height difference is accentuated in the northern marshes of the Atlantic Coast where the tall ditch-bank Spartina is often about the same height as the so-called short Spartina covering wide expanses of southern marshes. In addition, the northern marshes tend to have large expanses of $S$. patens with $S$. alterniflora only in restricted areas, especially near drainage ditches. Consequently, more larvae (mostly $T$. nigrovittatus) are reported nearest drainage ditches in northern marshes (New Jersey, Long Island, 
Massachusetts), while in southern marshes (North Carolina), larval distribution is fairly uniform across the Spartina marshes. To complicate matters, morphological variants of $T$. nigrovittatus, recognizable in the larval stage only, are found (Jamnback and Wall, 1959; Freeman, 1962; Freeman and Hansens, 1972; Dukes et al., 1974). Whether these are two separate species or two strains of T. nigrovittatus with different geographical distribution, and habitat requirement within the marsh is not known.

\subsubsection{Adult movement and dispersal}

Most tabanids are strong fliers and may fly up to 1 or $2 \mathrm{~km}$ from their breeding sites (Thornhill et al., 1971; Inoue et al., 1973; Thornhill and Hays, 1973). In mark-release-recapture studies, Sheppard et al. (1973) retrieved some T. lineola up to $6.4 \mathrm{~km}$ from the release point and Vorgetts (1973) retrieved two T. nigrovittatus at $8 \mathrm{~km}$ away.

Saltmarsh tabanids usually remain on the marsh after emergence, mating and often producing a first batch of eggs autogenously. The mating behavior of C. fuliginosus has been elegantly described by Catts and Olkowski (1972). The occurrence of autogeny has been shown in T. nigrovittatus, C. fuliginosus and C. atlanticus (Rockel, 1969a; Anderson, 1971; Bosler and Hansens, 1974). Some non-marsh Hybomitra display autogeny while others in the same genus do not (Thomas, 1972, 1973) and some African Chrysops apparently are autogenous (Duke et al., 1956), but T. quinquevittatus has been shown to be anautogenous in an upland area (Magnarelli and Pechuman, 1975). It is possible that the degree of autogeny in a population varies with geographical area and strains, as has been shown in mosquitoes. In any case, studies to date indicate that the saltmarsh tabanids generally do not begin their flight and host-seeking immediately after emergence. Trapping results indicate that mostly only those females which have laid eggs move.

Large numbers of $T$. nigrovittatus and $C$. fuliginosus have been found congregating in upland marsh-shrub areas. Dense shrubs and woods act as a partial barrier to further movement of these species. C. atlanticus moves more readily through the upland shrub-wood barrier. Open spaces (trails, roads, etc.) are the usual avenues for movement of these flies (Rockel and Hansens, 1970b; Hansens and Robinson, 1973; Dale and Axtell, 1974a; Schulze, 1974; Schulze et al., 1975).

Environmental factors including light, temperature and other climatic conditions influence light, mating and biting activities of these flies (Burnett and Hays, 1974). There are often definite peaks of activity during a 24-hour period for each species (Joyce and Hansens, 1968; Richardson and Wilson, 1969; Catts and Olkowski, 1972; Anderson, 1973; Kangwagye, 1973; Roberts, 1974; Dale and Axtell, 1975b). 


\subsubsection{Role of tabanids in marsh ecosystems}

The role of insects, including tabanids, in the marsh ecosystem is poorly understood (Teal, 1962; Davis and Gray, 1966; Marples, 1966; Cameron, 1972; Ranwell, 1972; Nixon and Oviatt, 1973; Daiber, 1974). Conclusions on the contribution of insects to the energy budget of marshes differ (Teal, 1962; McMahan et al., 1972). The few investigations carried out so far have concentrated on collections of adult insects, often with inappropriate sampling methods for insects and incomplete data collection. Examination of several ecological reports shows that usually there are few data on Tabanidae and any findings that might have been made are lumped under a larger taxonomic category - Diptera.

The role of tabanid larvae in the marsh can only be speculated upon. Their feeding habits are not known but it can be assumed that they are primary consumers and feed on detritus, algae, bacteria, etc., in the marsh soil as well as on other small invertebrates found in association with them (Gustafson and Lane, 1968; Wall, 1973; Kraeuter and Wolf, 1974; Bickley and Seek, 1975).

\subsection{ECONOMIC IMPORTANCE}

Many tabanids are aggressive biters of man, livestock and wild animals. Chrysops tend to circle the head and shoulders and persist in their attacks while other portions of the host are the target for many Tabanus. Attacks by tabanids disrupt the feeding and resting of livestock and can interfere with normal weight gains and milk production. People are annoyed and their outdoor activities are interrupted; this can be detrimental to the resort and recreation industries and property values, especially in the coastal areas (Gerhardt et al., 1973).

Tabanids are vectors of pathogens causing several diseases of man, livestock and wildlife (Zumpt, 1949; Anthony, 1962). Chrysops are intermediate hosts of the filarial worm, Loa loa, affecting man and monkeys in Africa (Gordon and Crewe, 1953; Crewe and Gordon, 1959; Duke, 1960). Development of Loa loa in Chrysops atlanticus under laboratory conditions has been demonstrated by Orihel and Lowrie (1975). Trypanosomes affecting livestock and wild animals are vectored by tabanids (Dixon et al., 1971; Davies and Clark, 1974; Krinsky and Pechuman, 1975). Mechanical transmission of the livestock diseases bovine anaplasmosis, equine infectious anemia and hog cholera by tabanids has been demonstrated (Wilson and Meyer, 1966; Hawkins et al., 1972, 1973; Tidwell et al., 1972; Wisenhutter, 1975). Tularemia ('deerfly fever') can be transmitted to humans by Chrysops (Klock et al., 1973; Hopla, 1974). Chrysops discalis is an intermediate host of a haemosporidian protozoan (DeGiusti et al., 1973; Sterling and DeGiusti, 1974). Encephalitis viruses pathogenic to humans have been isolated from tabanids (DeFoliart et al., 1969; Wright et al., 1970) resulting in recent increased interest in tabanids as disease vectors (Morris and DeFoliart, 1971; Gillies, 1974). 


\subsection{CONTROL}

Control of tabanids, especially saltmarsh species, is difficult and satisfactory methods have not been developed. The sparse distribution of larvae in wet soil often in ecologically critical areas, the large number of species with differing seasonal and biological characteristics, and the lack of basic research on the flies are contributing factors to our lack of adequate control procedures. There is a demand for tabanid control to protect people and livestock from the bites and potential disease transmission. Incorporation of tabanid control in broader programs of mosquito and biting-midge control is logical and often desired, especially in coastal areas (Gerry, 1950; Gerhardt et al., 1973; Hansens, 1973; Axtell, 1974).

\subsubsection{Larval control}

Chemical control of larval stages by treatment of the soil has been suggested and several chemicals have been tested (Hansens, 1956; Jamnback and Wall, 1959; Hoffman, 1960; Crewe and Williams, 1964; Wall and Marganian, 1973). However, it is not practical or desirable to treat a marsh with chemicals which give only partial control while having adverse affects on the non-target organisms. Larval control by water management can eliminate Chrysops larvae in selected marsh areas (Kneen, 1968; Anderson and Kneen, 1969), but any extensive impoundment would eliminate too much natural marsh.

\subsubsection{Adult control}

Repellents applied to livestock or man give a short period of relief from the biting of adult tabanids (Gilbert, 1957; Gerberg, 1966; Blume et al., 1971). Repellentimpregnated mesh shirts for people have some use (Catts, 1968; Grothaus et al., 1974).

Application of chemicals in an area for adult tabanid control can give some temporary relief but proper timing is difficult and the degree of control is usually much lower than is routinely achieved for mosquitoes (Howell et al., 1949; Brown and Morrison, 1955; Wilson, 1968a; Watanabe and Kamimura, 1971b; Henry, 1973; Axtell and Dukes, 1974). Treatment of livestock with insecticides gives temporary relief (Granett and Hansens, 1957; Hoffman et al., 1965).

The use of traps for control is an attractive concept due to their lack of environmental pollution, relatively low cost and ease of use. In fact, traps have been used routinely in some coastal areas for control of $T$. nigrovittatus attacking humans (Spencer, 1971), but their effectiveness is still questionable since there are limited data on the actual degree of control achieved, although many flies have been caught in the traps. Traps around pastures have given highly variable con- 
trol of tabanids on livestock (Wilson, 1968b; Tabachi and Yahima, 1969, 1970; Bauer and Wetzel, 1974). Since vegetative barriers impede movement of tabanids from the marsh, strategic plantings and retention of natural vegetation can be used along with traps to reduce the numbers of tabanids reaching the upland.

Since saltmarsh tabanids can reproduce autogenously, selective control of the adults which move to upland areas to attack people and animals will have minor affects on the population of larvae in the marsh.

\section{REFERENCES}

Adams, D.A. (1963) Factors influencing vascular plant zonation in North Carolina salt marshes. Ecology 44, 445-456.

Adkins, T.R., Ezell, W.B., Jr., Sheppard, D.C. and Askey, M.M., Jr. (1972) A modified canopy trap for collecting Tabanidae (Diptera).. J. Med. Entomol. 9, 183-185.

Anderson, J.F. (1971) Autogeny and mating and their relationship to biting in the saltmarsh deer fly, Chrysops atlanticus (Diptera: Tabanidae). Ann. Entomol. Soc. Am. 64, 1421-1424.

Anderson, J.F. (1973) Biting behavior of salt marsh deer flies (Diptera: Tabanidae). Ann. Entomol. Soc. Am. 66, 21-23.

Anderson, J.F. and Kneen, F.R. (1969) The temporary impoundment of salt marshes for the control of coastal deer flies. Mosquito News 29, 239-42.

Anderson, J.R., Olkowski, W. and Hoy, J.B. (1974) The response of tabanid species to $\mathrm{CO}_{2}$-baited insect flight traps in northern California (Diptera: Tabanidae). Pan-Pac. Entomol. 50, 255-268.

Anthony, D.W. (1957) Pyrethrum emulsions for the survey of tabanid larvae. J. Econ. Entomol. 50, $740-742$.

Anthony, D.W. (1962) Tabanidae as disease vectors. In: Biological Transmission of Disease Agents. (K. Maramorosch, Ed.) Academic Press, New York, pp. 93-107.

Axtell, R.C. (Ed.) (1974) Training manual for mosquito and biting fly control in coastal areas. (Univ. North Carolina Sea Grant Program Publ. UNC-SG-74-08.) 249 p.

Axtell, R.C. and Dukes, J.C. (1974) ULV chemical control of mosquitoes, Culicoides and tabanids in coastal North Carolina. Proc. Calif. Mosquito Control Assoc. 42, 99-101.

Axtell, R.C., Edwards, T.D. and Dukes, J.C. (1975) Rigid canopy trap for Tabanidae (Diptera). J. Georgia Entomol. Soc. 10, 67-73.

Bailey, N.S. (1947) Field notes on Tabanus nigrovittatus Macquart. Psyche 54, 62-64.

Bailey, N.S. (1948a) The hovering and mating of Tabanidae: A review of the literature with some original observations. Ann. Entomol. Soc. Am. 41, 403-412.

Bailey, N.S. (1948b) A mass collection and population survey technique for larvae of Tabanidae (Diptera). Bull. Brooklyn Entomol. Soc. 93, 22-29.

Bauer, B. and Wetzel, H. (1974) Versuche mit Fliegenfallen zur Tabanidenbekampfung auf der Weide. Tierarztl. Umsch. 29, 206-207.

Bennett, G.F. (1960) On some ornithophilic blood-sucking Diptera in Algonquin Park, Ontario, Canada. Can. J. Zool. 38, 377-389.

Bickley, W.E. and Seek, T.R. (1975) Insects in four Maryland marshes. Maryland Agric. Exp. Stn. Misc. Publ. No. 870.27 p.

Blickle, R.L. (1959) Observation on the hovering and mating of Tabanus bishoppi Stone (Diptera; Tabanidae). Ann. Entomol. Soc. Am. 52, 183-190.

Blume, R.R., Roberts, R.H., Eschle, J.F. and Matter, J. (1971) Tests of aerosols of deet for protection of livestock from biting flies. J. Econ. Entomol. 64, 1193-1196. 
Blume, R.R., Miller, J.A., Eschele, J.L., Matter, J.J. and Pickens, M.O. (1972) Trapping tabanids with modified Malaise traps baited with $\mathrm{CO}_{2}$. Mosquito News 32, 90-95.

Bosler, E.M. and Hansens, E.J. (1974) Natural feeding behavior of adult saltmarsh greenheads, and its relation to oogenesis. Ann. Entomol. Soc. Am. 67, 321-324.

Bonhag, P.F. (1951) The skeleto-muscular mechanism of the head and abdomen of the adult horsefly (Diptera: Tabanidae). Trans. Am. Entomol. Soc. 77, 131-202.

Boyes, J.W. and Wilkes, A. (1972) Chromosomes of Tabanidae (Diptera). Can. J. Genet. Cytol. 14, 95-104.

Bracken, G.K. and Thorsteinson, A.J. (1965) The orientation behavior of horse flies and deer flies (Tabanidae: Diptera). IV. The influence of some physical modifications of visual decoys on orientation of horse flies. Entomol. Exp. Appl. 8, 314-318.

Bracken, G.K., Hanec, W. and Thorsteinson, A.J. (1965) The orientation behavior of horse flies and deer flies (Tabanidae: Diptera). II. The role of some visual factors in the attractiveness of decoy silhouettes. Can. J. Zool. 40, 685-695.

Brown, A.W.A. and Morrison, P.E. (1955) Control of adult tabanids by aerial spraying. J. Econ. Entomol. 48, 125-9.

Burnett, A.M. and Hays, K.L. (1974) Some influences of meteorological factors on flight activity of female horse flies (Diptera: Tabanidae). Environ. Entomol. 3, 515-521.

Burns, E.C. and Chapin, J.B. (1969) Arthropods in the diet of the cattle egret (Bubulcus ibis) in southern Louisiana. J. Econ. Entomol. 62, 736-738.

Cameron, A.E. (1926) Bionomics of the Tabanidae of the Canadian prairie. Bull. Entomol. Res. $17,1-42$.

Cameron, A.E. (1934) The life-history and structure of Haematopota pluvialis Linne (Tabanidae). Trans. R. Soc. Edinb. 58, 211-250.

Cameron, G.N. (1972) Analysis of insect trophic diversity in two salt marsh communities. Ecology $53,58-73$.

Carrasco, Z.F. (1972) Tabanos del Peru. Rev. Peruana Entomol. Agric. 15, 317-323.

Catts, E.P. (1968) Deet impreganted shirt repels biting flies. J. Econ. Entomol. 61, 1765.

Catts, E.P. (1970) A canopy trap for collecting Tabanidae. Mosquito News 30, 472-474.

Catts, E.P. and Olkowski, W. (1972) Biology of Tabanidae (Diptera): Mating and feeding behavior of Chrysops fuliginosus. Environ. Entomol. 1, 448-453.

Chvála, M., Lyneborg, L. and Moucha, J. (1972) The Horse Flies of Europe (Diptera, Tabanidae). (Entomol. Soc. Copenhagen and E.W. Classey Ltd, Hampton, England) 499 p.

Cooper, A.W. (1974) Salt marshes. In: Coastal Ecological Systems of the United States, Vol. II. (H.T. Odum, B.J. Copeland and E.A. McMahan, Eds.) pp. 55-98. (Conservation Foundation, Washington, D.C.)

Crewe, W. and Gordon, R.M. (1959) The immediate reaction of the mammalian host to bite of uninfected Chrysops and of Chrysops infected with human and with monkey Loa. Ann. Trop. Med. Parasitol. 58, 343-346.

Crewe, W. and Williams, P. (1964) Studies on the control of the vectors in Loiasis in West Africa. VII. The effects of low concentrations of dieldrin in the mud of natural tabanid breeding-sites in the rain forest of the Cameroons. Ann. Trop. Med. Parasitol. 58, 343-346.

Daiber, F.C. (1974) Salt marsh plants and future coastal salt marshes in relation to animals. In: Ecology of Halophytes. (R.J. Reimold and W.H. Queen, Eds.) pp. 475-507. (Academic Press, New York.)

Dale, W.E. and Axtell, R.C. (1975a) Salt marsh Tabanidae (Diptera): Comparison of abundance and distribution in Spartina and Juncus habitats. J. Med. Entomol. 12, (in press).

Dale, W.E. and Axtell, R.C. (1975b) Flight of the salt marsh Tabanidae (Diptera), Tabanus nigrovittatus, Chrysops atlanticus and C. fuliginosus: Correlation with temperature, light, moisture and wind velocity. J. Med. Entomol. 12, 551-557. 
Davies, D.M. (1959) Seasonal variation of tabanids (Diptera) in Algonquin Park, Ontario. Can. Entomol. 91, 548-553.

Davies, R.B. and Clark, G.G. (1974) Trypanosomes from elk and horse flies in New Mexico. $J$. Wildl. Dis. 10, 63-65.

Davis, L.V. and Gray, I.E. (1966) Zonal and seasonal distribution of insects on North Carolina salt marshes. Ecol. Monogr. 36, 275-295.

DeFoliart, G.R. and Morris, C.D. (1967) A dry ice-baited trap for the collection and field storage of hematophagous Diptera. J. Med. Entomol. 4, 360-362.

DeGuisti, D.L., Sterling, C.R. and Dobrzechowski, D. (1973) Transmission of the chelonian haemoproteid Haemoproteus metchnikovi by a tabanid fly Chrysops callidus. Nature 242, 50-51.

DeFoliart, G.R., Anslow, R.O., Hanson, R.P., Morris, C.D., Papadopoulos, O. and Sather, G.E. (1969) Isolation of Jamestown Canyon serotype of California encephalitis virus from naturally infected Aedes mosquitoes and tabanids. Am. J. Trop. Med. Hyg. 18, 440-447.

Dickerson, G. and Lavoipierre, M.M.J. (1959) Studies on the methods of feeding of blood-sucking arthropods III. The method by which Haematopota pluvialis obtains its blood-meal from the mammalian host. Ann. Trop. Med. Parasitol. 53, 465-472.

Dinsmore, J.J. (1973) Foraging success of cattle egrets, Bubulcus ibis. Am. Midl. Nat. 89, 242-246.

Dixon, J.B., Cull, R.S., Dunbar, I.F., Greenhill, R.J., Grimshaw, C.G., Hill, M.A., Landeg, F.J. and Miller W.M. (1971) Non-cyclical transmission of trypanosomiasis in Uganda. I. Abundance and biting behavior of Tabanidae and Stomoxys. Vet. Rec. 89, 228-233.

Dubitskii, A.M., Deshevyh, N.D. and Andreeva, R.V. (1974) Activation conditions of resting sporangia of Coelomomyces milkoi under laboratory conditions. Parazitologiia 8, 175-178. (In Russian).

Duke, B.O.L. (1960) Studies on the biting fly habits of Chrysops. VIII. The biting cycle of nulliparous C. silacea and C. dimidata (Bombe form). Ann. Trop. Med. Parasitol. 54, 147-155.

Dukes, J.C. and Hays, K.L. (1971) Seasonal distribution and parasitism of eggs of Tabanidae in Alabama. J. Econ. Entomol. 64, 886-889.

Dukes, J.C., Edwards, T.D. and Axtell, R.C. (1974a) Distribution of larval Tabanidae (Diptera) in a Spartina alterniflora salt marsh. J. Med. Entomol. 11, 79-83.

Dukes, J.C., Edwards, T.D. and Axtell, R.C. (1974b) Associations of Tabanidae (Diptera) larvae with plant species in salt marshes, Carteret County, North Carolina. Environ Entomol. 3, 280-286.

Easton, E.R., Price, M.A. and Graham, O.H. (1968) The collection of biting flies in west Texas with Malaise and animal-baited traps. Mosquito News 28, 465-469.

Edwards, T.D., Dukes, J.C. and Axtell, R.C. (1974) Soil-washing apparatus for recovery of tabanid larvae and other invertebrates. J. Georgia Entomol. Soc. 9, 32-35.

El-Ziady, S. and Hefnawy, T. (1970) External and internal structure of the full-grown larva and pupa of Tabanus taeniola P. de B. (Diptera: Tabanidae). Bull. Entomol. Soc. Egypt. 54, 415-431.

Everett, R. and Lancaster, J.L. (1968) A comparison of animal and dry-ice baited traps for the collection of tabanids. J. Econ. Entomol. 61, 863-864.

Ezell, W.B., Sheppard, D.C., Adkins, T.R., Jr. and Pechuman, L.L. (1974) An annotated list of the Tabanidae (Diptera) of South Carolina. J. Georgia Entomol. Soc. 9, 91-99.

Fairchild, G.B. (1969a) Climate and the phylogeny and distribution of Tabanidae. Bull. Entomol. Soc. Am. 15, 7-11.

Fairchild, G.B. (1969b) Notes on Neotropical Tabanidae XII. Classification and distribution, with keys to genera and subgenera. Arq. Zool. São Paulo 17, 199-255.

Fairchild, G.B. (1971) Tabanidae. In: A Catalogue of the Diptera of the Americas South of the United States, section 28, pp. 1-163. (Museu de Zoologia, Universidade de São Paulo, Brazil.)

Fogarty, M.J. and Hetrick, W.M. (1973) Summer food habits of cattle egrets in north central Florida. Auk 90, 268-280. 
Foster, C.H., Renaud, G.D. and Hays, K.L. (1973) Some effects of the environment on oviposition by Chrysops (Diptera: Tabanidae). Environ Entomol. 2, 1048-1050.

Freeman, J.V. (1962) Biology, ecology and taxonomy of Tabanus nigrovittatus Macquart (Diptera: Tabanidae) of the salt marsh at Leeds Point, New Jersey. (Ph.D. thesis, Rutgers University, New Brunswick, N.J.) 209 pp.

Freeman, J.V. and Hansens, E.J. (1972) Collecting larvae of the salt marsh greenhead Tabanus nigrovittatus and related species in New Jersey: Comparison of methods. Environ. Entomol. 1, 653-658.

Gerberg, E.J. (1966) Field and laboratory tests with 2,2,4-trimethyl-1,3-pentanediol (TMPD). J. Econ. Entomol. 59, 872-875.

Gerhardt, R.R., Dukes, J.C., Falter, J.M. and Axtell, R.C. (1973) Public opinion on insect pest management in coastal North Carolina. N. C. Agric. Extension Serv. Misc. Publ. No. 97. 81 p.

Gerry, B.I. (1950) Salt marsh fly control as an adjunct to mosquito control in Massachusetts. Proc. N. J. Mosquito Exterm. Assoc. 37, 189-193.

Gilbert, I.H. (1957) Evaluation of repellents against mosquitoes and deer flies in Oregon. J. Econ. Entomol. 50, 46- 48.

Gillies, M.T. (1974) Methods for assessing the density and survival of bloodsucking Diptera. Annu. Rev. Entomol. 19, 345-362.

Goodwin, J.T. (1972) Immature stages of some eastern Nearctic Tabanidae (Diptera). I. Introduction and the genus Chrysops Meigen. J. Georgia Entomol. Soc. 7, 98-109.

Goodwin, J.T. (1973a) Immature stages of some eastern Nearctic Tabanidae (Diptera). II. Genera of the Tribe Diachlorini. J. Georgia Entomol. Soc. 8, 5-11.

Goodwin, J.T. (1973b) Immature stages of some eastern Nearctic Tabanidae (Diptera). III. The genus Tabanus Linneaus. J. Georgia Entomol. Soc. 8, 82-99.

Goodwin, J.T. (1973c) Immature stages of some eastern Nearctic Tabanidae (Diptera). IV. The genus Merycomyia. J. Tennessee Acad. Sci. 48, 115-118.

Goodwin, J.T. and Murdoch, W.P. (1974) A study of some immature Neotropical Tabanidae (Diptera). Ann. Entomol. Soc. Am. 67, 85-133.

Gordon, R.R. and Crewe, W. (1953) The deposition of the infective stage of Loa loa by Chrysops silacea and the early stages of its migration to the deeper tissues of the mammalian host. Ann. Trop. Med. Parasitol. 47, 74-85.

Granger, C.A. (1970) Trap design and color as factors in trapping the salt marsh greenhead fly. $J$. Econ. Entomol. 63, 1670-1672.

Granett, P. and Hansens, E.J. (1957) Further observations on the effect of biting fly control on milk production in cattle. J. Econ. Entomol. 50, 332-336.

Gringrich, R.E. (1965) Telohania tabani sp. n. a microsporidian from larvae of the black horse fly Tabanus atratus Fabricius. J. Invert. Pathol. 7, 236-240.

Grothaus, R.H., Gouck, H.K., Weidhaas, D.E. and Jackson, S.C. (1947) Wide-mesh netting, an improved method of protection against blood-feeding Diptera. Am. J. Trop. Med. Hyg. 23, 533.

Gustafson, J.F. and Lane, R.S. (1968) An anotated bibliography of literature on salt marsh insects and related arthropods in California. Pan-Pac. Entomol. 44, 327-331. (Supplemented lists available from senior author.)

Hafez, M., El-Ziady, S., Hefnawy, T. (1970) Studies on the feeding habits of female Tabanus taeniola P. de B. (Diptera: Tabanidae). Bull. Entomol. Soc. Egypt. 54, 365-376.

Hansens, E.J. (1952) Some observations on the abundance of salt marsh greenheads. Proc. N. J. Mosquito Exterm. Assoc. 39, 93-98.

Hansens, E.J. (1956) Granulated insecticides against greenhead (Tabanus) larvae in the salt marsh. J. Econ. Entomol. 49, 401-403.

Hansens, E.J. (1973) Integrated control of blood-sucking Diptera in seashore areas. Proc. N. J. Mosquito Exterm. Assoc. 60, 96-102. 
Hansens, E.J. and Robinson, J.W. (1973) Emergence and movement of the saltmarsh deer flies Chrysops fuliginosus and Chrysops atlanticus. Ann. Entomol. Soc. Am. 66, 1215-1218.

Hansens, E.J., Bosler, E.M. and Robinson, J.W. (1971) Use of traps for study and control of saltmarsh greenhead flies. J. Econ. Entomol. 64, 1481-1486.

Howell, D.E., Eddy, G.W. and Cutt, R.L. (1949) Effect on horse fly populations of aerial spray to wooded areas. J. Econ. Entomol. 42, 644-646.

Hawkins, J.A., Adams, W.V., Cook, L., Wilson, B.H. and Roth, E.E.(1972) Transmission of equine infectious anemia with the horse fly Tabanus fuscicostatus Hine. Proc. 76th Annu. Meet. U. S. Anim. Health Assoc., pp. 227-230.

Hawkins, J.A., Adams, W.V., Cook, L., Wilson, B.H. and Roth, E.E. (1973) Role of horse fly (Tabanus fuscicostatus Hine) and stable fly (Stomoxys calcitrans L.) in transmission of equine infectious anemia to ponies in Louisiana. Am. J. Vet. Res. 34, 1583-1586.

Hennig, W. (1952) Die Larvenformen der Dipteren, vol. 3. (Akademie Verlag, Berlin) 628 p.

Henry, H.M. (1973) Control and behavior of coastal South Carolina Tabanidae (Diptera). (Ph.D. thesis, Clemson Univ., Clemson, S. C.) 84 pp.

Hoffman, R.A. (1960) Laboratory evaluation of several insecticides against Chrysops larvae. $J$. Econ. Entomol. 53, 262-263.

Hoffman, R.A., Berry, I.L. and Graham, O.H. (1965) Control of flies in cattle by frequent, lowvolume mist spray applications of Ciodrin. J. Econ. Entomol. 58, 815-817.

Hopla, C.E. (1974) The ecology of tularemia. Adv. Vet. Sci. Comp. Med. 18, 25-53.

Hotchkiss, N. (1970) Common marsh plants of the United States and Canada. U. S. Dept. Interior, Bur. Sport Fish. Wildl., Resource Publ. No. 93. 99 pp.

Inoue, T., Kamimura, K. and Watanabe, M. (1973) A quantitative analysis of dispersal in a horsefly, Tabanus iyoensis Shiraki and its application to estimate the population size. Res. Popul. Ecol. 14, 209-233.

Jackson, T.O. and Wilson, B.H. (1966) Parasitism of tabanid (Diptera: Tabanidae) eggs in four areas of Southern Louisiana. Ann. Entomol. Soc. Am. 59, 261-267.

James, H.G. (1963) Larval habitats, development development, and parasites of some Tabanidae (Diptera) in southern Ontario. Can. Entomol. 95, 1223-1232.

Jamnback, H. and Wall, W. (1959) The common salt marsh Tabanidae of Long Island, New York. Bull. N. Y. State Mus. Sci. Serv. No. 375. 77 pp.

Jenkins, D.W. (1964) Pathogens, parasites and predators of medically important arthropods. Bull. WHO 30, suppl. $150 \mathrm{pp}$.

Jenni, D.A. (1969) A study of the ecology of four species of herons during the breeding season at Lake Alice, Alachua County, Florida. Ecol. Monogr. 39, 245-270.

Johnson, A.W. and Hays, K.L. (1973) Some predators of immature Tabanidae (Diptera) in Alabama. Environ. Entomol. 2, 1116-1117.

Jones, C.M. (1953) Biology of Tabanidae in Florida. J. Econ. Entomol. 46, 1108-1109.

Jones, C.M. and Anthony, D.W. (1964) The Tabanidae (Diptera) of Florida. U. S. D. A., Agric. Res. Serv., Agric. Tech. Bull. No. 1295. 85 pp.

Joyce, J.M. and Hansens, E.J. (1968) The influence of weather on the activity and behavior of greenhead flies, Tabanus nigrovittatus Macquart and Tabanus lineola Fabricius. J. N. Y. Entomol. Soc. $76,72-80$.

Kangwagye, T.N. (1973) Diurnal and nocturnal biting activity of flies (Diptera) in western Uganda. Bull. Entomol. Res. 63, 17-29.

Klock, L.E., Olsen, P.F. and Fukushima, T. (1973) Tularemia epidemic associated with the deerfly. J. Am. Med. Assoc. 226, 149-152.

Kneen, F.R. (1968) Water management in the control of Chrysops niger. Proc. N. J. Mosquito Exterm. Assoc. 55, 94-98. 
Knox, P.C. and Hays, K.L. (1972) Attraction of Tabanus spp. (Diptera: Tabanidae) to traps baited with carbon dioxide and other chemicals. Environ. Entomol. 1, 323-326.

Knudsen, A.B. and Rees, D.M. (1967) Egg laying habits of the deer fly Chrysops discalis Williston, in marshes bordering the Great Salt Lake, Utah. Proc. Calif. Mosquito Control Assoc. 35, 103-105.

Kraeuter, J.N. and Wolf, P.L. (1974) The relationship of marine macroinvertebrates to salt marsh plants. In: Ecology of Halophytes. (R.J. Reimold and W.H. Queen, Eds.) pp. 449 462. (Academic Press, New York.)

Krinsky, W.L. and Pechuman, L.L. (1975) Trypanosomes in horse flies and deer flies in central New York State. J. Parasitol. 61, 12-16.

Lall, S.B. (1970a) Nectar sugars as chemostimulants for the tarsal taste sensilla of haematophagous tabanids (Diptera). J. Med. Entomol. 7, 103-106.

Lall, S.B. (1970b) Feeding behavior of haematophagous Tabanids (Diptera). J. Med. Entomol. 7, $115-119$.

Lall, S.B. (1970c) Loci, structure and function of contact chemical sensilla in haematophagous tabanids (Diptera). J. Med. Entomol. 7, 205-222.

Lall, S.B. and Davies, D.M. (1967) Tarsal sensitivity of female tabanid flies to sucrose and sodium chloride. Can. J. Zool. 45, 461-464.

Lall, S.B. and Davies, D.M. (1971) An intergeneric comparison of cephalic structure in Tabanids (Diptera) in relation to feeding habits. J. Med. Entomol. 8, 700-706.

Leclercq, M. (1960) Révision systématique et biogéographique des Tabanidae paléarctique et Chrysopinae. Mem. Inst. R. Sci. Nat. Belg. 63, 1-77.

Leclercq, M. (1967) Révision systématique et biogéographique des Tabanides paléarctiques, Vol. II. Tabanidae. Mem. Inst. R. Sci. Nat. Belg. 80, 1-237.

MacCreary, D. (1940) Report on the Tabanidae of Delaware. Bull. Delaware Univ. Agric. Exp. Stn. No. $226.41 \mathrm{p}$.

Mackerras, I.M. (1954) The classification and distribution of Tabanidae (Diptera). I. General review. Aust. J. Zool. 2, 431-454.

Mackerras, I.M. (1955a) The classification and distribution of Tabanidae (Diptera). II. History: morphology: classification: subfamily Pangoniinae. Aust. J. Zool. 3, 439-511.

Mackerras, I.M. (1955b) The classification and distribution of Tabanidae (Diptera). III. Subfamilies Scepsidinae and Chrysopinae. Aust. J. Zool. 3, 583-633.

Mackerras, I.M. (1956a) The Tabanidae (Diptera) of Australia. I. General review. Aust. J. Zool. 4, $376-407$.

Mackerras, I.M. (1956b) The Tabanidae (Diptera) of Australia. II. Subfamily Pangoniidae, Tribe Pangoniini. Aust. J. Zool. 4, 408-443.

Mackerras, I.M. (1971) The Tabanidae (Diptera) of Australia. Vubfamily Tabanini. Aust. J. Zool. suppl. 4, 54 p.

Mackerras, I.M. (1972) Melonesian-Pacific Tabanus (Diptera): Tabanidae. Pac. Insects 14, 133-149.

Magnarelli, L.A. and Pechuman, L.L. (1975) Ovarian studies of Tabanus quinquevittatus (Diptera: Tabanidae). J. Med. Entomol. 11, 687-690.

Marples, T.G. (1966) A radionuclide tracer study of arthropod food chains in a Spartina marsh ecosystem. Ecology 47, 270-277.

Matthysse, J.G., Mock, D.E. and Netherton, H.R. (1974). Seasonal flight period and relative abundance of Tabanidae (Diptera) near Ithaca, New York. Ann. Entomol. Soc. Am. 67, 158-166.

McMahan, E.A., Knight, R.L. and Camp, A.R. (1972) A comparison of microarthropod populations in sewage-exposed and sewage-free Spartina salt marshes. Environ. Entomol. 1, 244-252.

Morgan, N.O. and Uebel, E.C. (1974) Efficacy of the Assateague insect trap in collecting mosquitoes and biting flies in a Maryland salt marsh. Mosquito News 34, 196-199.

Morris, C.D. and DeFoliart, G.R. (1971) Seasonal parous rates in Hybomitra lasiophthalma (Diptera: Tabanidae). J. Med. Entomol. 8, 207-208. 
Neys, W.A., Lavigne, R.S. and Roehrkasse, G.P. (1971) Attraction of Wyoming Tabanidae (Diptera) to decoys suspended from modified Manitoba fly traps. Univ. Wyoming. Agric. Exp. Stn. Sci. Monogr. No. 22. 11 p.

Nixon, S.W. and Oviatt, C.A. (1973) Ecology of a New England salt marsh. Ecol. Monogr. 43, 463-498.

Oldroyd, H. (1952) The Horse-Flies (Diptera: Tabanidae) of the Ethiopian Region, Vol. I: Haematopota and Hippocentrum. (Br. Mus. Nat. Hist., Lond.) 226 p.

Oldroyd, H. (1954) The Horse-Flies (Diptera: Tabanidae) of the Ethiopian Region, Vol. V: Tabanus and Related Genera. (Br. Mus. Nat. Hist., Lond.) 341 p.

Oldroyd, H. (1957) The Horse-Flies (Diptera: Tabanidae) of the Ethiopian Region, Vol. III : Subfamilies Chrysopinae, Scepsidinae and Pangoniinae and a revised classification. (Br. Mus. Nat. Hist. Lond.) 489 p.

Oldroyd, H. (1969) Diptera Brachycera. Section (a) Tabanoidea and Asiloidea. In: Handbooks for the Identification of British Insects, Vol. 9, part 4 (R. Entomol. Soc., Lond.) 132 p.

Olsufjev, N.G. (1969a) On the taxonomy and distribution of Tabanidae (Diptera) of the Palaearctic region. Acta Entomol. Bohemoslov. 66, 115-121.

Olsufjev, N.G. (1969b) Tabanidae-Slepni. In: Opredelital nasekomych Evropejsko, casti SSR. 5, 481-500 (figs. 292-303). (In Russian).

Orihel, T.C. and Lowrie, R.C., Jr. (1975) Loa loa: development to the infective stage in an American deerfly, Chrysops atlanticus. Am. J. Trop. Med. Hyg. 24, 610-615.

Orminati, S.A. and Hansens, E.J. (1974) The biology of Tabanus lineola lineola F. Ann. Entomol. Soc. Am. 67, 937-939.

Pechuman, L.L. (1972) The horse flies and deer flies of New York (Diptera: Tabanidae). Search, Agric. (N. Y. Agric. Exp. Stn.) 2(5) 72 p.

Pechuman, L.L. (1973) The horse flies and deer flies of Virginia (Diptera: Tabanidae). The Insects of Virginia: No. 6. Bull. Res. Div., Virginia Polytech. Inst., State Univ., Blacksburg, No. 81. $92 \mathrm{p}$.

Pernot-Visentin, O. and Beaucournu-Saguez, F. (1974) Les Tabanidae (Diptera) de France. Bull. Mens. Soc. Linn. Lyon 43, 142-155.

Pino, G., Candia, V., Letelier, S., Ostoic, A., Sanchez, J. and Sanchez, V. (1973) Los tabanos de Chile (Diptera: Tabanidae). 4. Estudios ecologicos preliminares en Fray Jorge. Rev. Chil. Entomol. 7, 207-216.

Philip, C.B. (1931) The Tabanidae (horseflies) of Minnesota. Tech. Bull. Minn. Agric. Exp. Stn. No. 80,132 p.

Philip, C.B. (1954) New North American Tabanidae. VIII. Notes on and keys to the genera and species of Pangoniinae exclusive of Chrysops. Rev. Brazil Entomol. 2, 13-60.

Philip, C.B. (1955) New North American Tabanidae. IX. Notes on and keys to the genus Chrysops Meigen. Rev. Brazil Entomol. 3, 47-128.

Philip, C.B. (1957) A new era in ideas of systematic relationships of world Tabanidae (Diptera) inaugurated by Mackerras and its impact on nomenclature of horseflies of the western hemisphere. Ann. Entomol. Soc. Am. 50, 550-555.

Philip, C.B. (1965) Family Tabanidae. In: A Catalog of the Diptera of America North of Mexico. (A. Stone, C.W. Sabrosky, W.W. Wirth, R.H. Foot and J.R. Coulson, Eds.) pp. 319-342. (U. S. Dept. Agric., Agric. Res. Serv., Agric. Handb. No. 276, Wash. D. C.)

Philip, C.B. (1966) New North American Tabanidae. XVIII. New species and addenda to a Nearctic catalog. Ann. Entomol. Soc. Am. 59, 519-527.

Philip, C.B. and Coscaron, S. (1971) Comparative terminalia of certain Nearctic and Palaearctic chrysopsine flies. Tabanidae. Ann. Entomol. Soc. Am. 64, 157-162.

Pratt, G.K. and Pratt, H.D. (1972) Records of Tabanidae (Diptera) collected on flowers. Mosquito News 32, 632-633. 
Ranwell, D.S. (1972) Ecology of Salt Marshes and Sand Dunes. (Chapman and Hall, London.) $258 \mathrm{pp}$.

Richardson, C.G. and Wilson, B.H. (1969) Daily flight activity of male Tabanus lineola var. hinellus Philip (Diptera: Tabanidae) in the estuarine area of Louisiana. J. Med. Entomol. 6, 276-277.

Roberts, L.W. and Wilson, B.H. (1967) Predation on horse flies by two bembicine wasp species in certain areas of southern Louisiana. J. Econ. Entomol. 60, 412-415.

Roberts, R.H. (1966) A technique for rearing the immature stages of Tabanidae (Diptera). Entomol. News 77, 79-82.

Roberts, R.H. (1967) Feeding of horseflies (Tabanidae: Diptera) on plant juices. Entomol. News $78,250-251$.

Roberts, R.H. (1970a) Tabanidae collected in a Malaise trap baited with $\mathrm{CO}_{2}$. Mosquito News 30 , $52-53$.

Roberts, R.H. (1970b) Color of Malaise trap and the collection of Tabanidae. Mosquito News 30, $567-571$.

Roberts, R.H. (1971) Effect of $\mathrm{CO}_{2}$ on collection of Tabanidae in Malaise traps. Mosquito News 31, $551-558$.

Roberts, R.H. (1974) Duirnal activity of Tabanidae based on collections in Malaise traps. Mosquito News 34, 220-223.

Rockel, E.G. (1969a) Autogeny in the deerfly, Chrysops fuliginosus. J. Med. Entomol. 6, 140-142.

Rockel, E.G. (1969b) Marsh physiography: Influence on distribution of intertidal organisms. Proc. N. J. Mosquito Exterm. Assoc. 56, 102-116.

Rockel, E.G. and Hansens, E.J. (1970a) Distribution of larval horse flies and deer flies (Diptera: Tabanidae) of a New Jersey salt marsh. Ann. Entomol. Soc. Am. 63, 681-684.

Rockel, E.G. and Hansens, E.J. (1970b) Emergence and flight activity of salt-marsh horse flies and deer flies. Ann. Entomol. Soc. Am. 63, 27-31.

Schulze, T.L. (1974) The effects of some environmental factors in the daily and seasonal movements of the salt marsh greenhead, Tabanus nigrovittatus Macquart (Diptera: Tabanidae). (Ph.D. thesis, Rutgers University, New Brunswick, N. J.) 70 p.

Schulze, T.L., Hansens, E.J. and Trout, J.R.(1975) Some environmental factors affecting the daily and seasonal movements of the salt marsh greenhead, Tabanus nigrovittatus. Environ. Entomol. 4, 965-971.

Service, M.W. (1973) Observations on the flight activities of Chrysops caecutiens L. Ann. Trop. Med. Parasitol. 67, 445-454.

Shamsuddin, M. (1966) A Bathymermis species (Mermithidae, Nematoda) parasitic on larval Tabanidae). Quaest. Entomol. 2, 253-256.

Sheppard, D.C., Wilson, B.H. and Hawkins, J.A. (1973) A device for self-marking of Tabanidae. Environ. Entomol. 2, 960-961.

Siegfried, W.R. (1971) The food of the Cattle Egret. J. Appl. Ecol. 8, 447-468.

Smith, G.E., Breeland, S.G. and Pickard, E. (1965) The Malaise trap - a survey tool in medical entomology. Mosquito News 25, 398-400.

Snoddy, E.L. (1969) On the behavior and food habits of the cattle egret, Bubulcus ibis (L.). J. Georgia Entomol. Soc. 4, 156-158.

Snoddy, E.L. (1970) Trapping deer flies with colored weather balloons (Diptera: Tabanidae). J. Georgia Entomol. Soc. 5, 207-209.

Spencer, R.M. (1971) A mechanical approach to the abatement of the greenhead fly Tabanus nigrovittatus. Proc. N. J. Mosquito Exterm. Assoc. 58, 71-77.

Spratt, D.M. and Wolf, G. (1972) A tachinid parasite of Dasybasis oculata (Ricardo) and Dasybasis hebes (Walker) (Diptera, Tabanidae). J. Aust. Entomol. Soc. 11, 260.

Stammer, H.J.(1924) Die Larven der Tabanidae (Diptera). Ann. Entomol. Soc. Am. 23, 261-304.

Sterling, C.R. and De Giusti, D.L. (1974) Fine structure of differentiating oocysts and mature 
sporozoites of Haemoproteus metchnikovi in its intermediate host Chrysops callidus. J. Protozool. 21, 276-283.

Takahasi, H. (1962) Fauna Japonica: Tabanidae. (Biogeogr. Soc. Jap., Nat. Sci. Mus., Tokyo.) 143 p. Tashiro, H. and Schwardt, H.H. (1953) Some natural enemies of horse flies in New York. J. Econ. Entomol. 46, 680-681.

Teal, J.M. (1962) Energy flow in the salt marsh ecosystem of Georgia. Ecology 43, 614-624.

Terteryan, A.Y. (1973) On the morphology of the male genitalia of horse flies (Diptera, Tabanidae) of the Armenian SSR. Entomol. Rev. 51, 345-354. (translation from Entomologicheskoe Obozrenie 51,373-580).

Teskey, H.J. (1962) A method and apparatus for collecting larvae of Tabanidae (Diptera) and other invertebrate inhabitants of wetlands. Proc. Entomol. Soc. Ontario 92, 204-206.

Teskey, H.J. (1969) Larvae and pupae of some eastern North American Tabanidae (Diptera). Mem. Entomol. Soc. Can. No. 63. 147 p.

Thomas, A.W. (1971) An apparatus and method for the field separation of tabanid larvae (Diptera: Tabanidae) from moss. Quaest. Entomol. 7, 407-408.

Thomas, A.W. (1972) Physiological age structure of adult tabanid populations (Diptera: Tabanidae) in Alberta, Canada. J. Med. Entomol. 9, 295-300.

Thomas, A.W. (1973) Follicle developmental stages in blood-seeking horseflies (Diptera: Tabanidae) in Alberta, Canada. J. Med. Entomol. 10, 325-328.

Thompson, P.H. (1967) Tabanidae of Maryland. Trans. Am. Entomol. Soc. 93, 463-519.

Thompson, P.H. (1969) Collecting methods for Tabanidae (Diptera). Ann. Entomol. Soc. Am. 62, $50-57$.

Thompson, P.H. (1970) Larvae Tabanidae (Diptera) of the Great Swamp, New Jersey. Ann. Entomol. Soc. Am. 63, 343-344.

Thompson, P.H. (1971a) Tabanidae of Maryland, addenda (Diptera). Proc. Entomol. Soc. Wash. 73, 378-381.

Thompson, P.H. (1971b) Larval Tabanidae (Diptera) of the Patuxent Wildlife Research Center, Laurel, Maryland. Ann. Entomol. Soc. Am. 64, 956-957.

Thompson, P.H. (1972) Tabanidae of Patuxent Wildlife Research Center, Laurel, Maryland. The second year. (Diptera). Proc. Entomol. Soc. Wash. 74, 188-192.

Thompson, P.H. (1973) Tabanidae (Diptera) of Texas. I. Coastal marsh species, West Galveston Bay; incidence, frequency, abundance and seasonal distribution. Proc. Entomol. Soc. Wash. 75, 359-364.

Thompson, P.H. and Gregg, E.J. (1974) Structural modifications and performance of the modified animal trap and the modified Manitoba trap for collection of Tabanidae (Diptera). Proc. Entomol. Soc. Wash. 76, 119-122.

Thompson, P.H. and Pechuman, L.L. (1970) Sampling populations of Tabanus quinquevittatus about horses in New Jersey, with notes on the identity and ecology. J. Econ. Entomol. 63, 151-155.

Thornhill, A.R., Gilbert, J.P. and Hays, K.L. (1971) How far do horse flies and deer flies fly? Highlights Agric. Res., Auburn. Univ., Ala. 18, 5.

Thornhill, A.R. and Hays, K.L. (1972) Dispersal and flight activities of some species of Tabanus (Diptera: Tabanidae). Environ. Entomol. 1, 602-606.

Thorsteinson, A.J., Bracken, G.K. and Hanec, W. (1965) The orientation behaviour of horse flies and deer flies (Tabanidae, Diptera). III. The use of traps in the study of orientation of tabanids in the field. Entomol. Exp. Appl. 8, 189-192.

Thorsteinson, A.J., Bracken, G.K. and Tostowaryk, W. (1966) The orientation behavior of horse flies and deer flies (Tabanidae: Diptera) V. The influence of the number and inclination of reflecting surfaces on attractiveness to tabanids of glossy black polyhedra. Can. J. Zool. 44, 275-279.

Tidwell, M.A. (1973) The Tabanidae (Diptera) of Louisiana. Tulane Stud. Zool. Bot. 18, 1-95. 
Tidwell, M.A. and Hays, K.L. (1971) Oviposition preferences of some Tabanidae (Diptera). Ann. Entomol. Soc. Am. 64, 547-549.

Tidwell, M.A. and Tidwell, M.A. (1973) Larvae and pupae of five eastern North American Tabanus species (Diptera: Tabanidae). Ann. Entomol. Soc. Am. 62, 390-398.

Tidwell, M.A., Dean, W.D., Tidwell, M.A., Combs, G.P., Anderson, D.W., Cowart, W.O. and Axtell, R.C. (1972) Transmission of hog cholera virus by horseflies (Tabanidae: Diptera). Am. J. Vet. Res. 33, 615-622.

Vorgetts, L.J., Jr. (1973) The use of box traps for studying populations of greenhead flies (Tabanus nigrovittatus Macq.). (Msc. thesis, Rutgers University, New Brunswick, New Jersey) 97 p.

Wall, W.J., Jr. (1973) The intertidal sand and salt marsh invertebrate fauna associated with the bloodsucking Diptera of Cape Cod, Massachusetts. Environ. Entomol. 2, 681-684.

Wall, W.J., Jr. and Doane, O.W., Jr. (1960) A preliminary study of the bloodsucking Diptera on Cape Cod, Massachusetts. Mosquito News 20, 39-44.

Wall, W. and Jamnback, H. (1957) Sampling methods used in estimating larval populations of salt marsh tabanids. J. Econ. Entomol. 50, 389-391.

Wall, W.J., Jr. and Marganian, V.M. (1973) Control of salt marsh Culicoides and Tabanus larvae in small plots with granular organophosphorous pesticides, and the direct effect on other fauna. Mosquito News 33, 88-93.

Wallace, F.G. (1966) The trypanosomatid parasites of insects and arachnids. Exp. Parasitol. 18, $124-193$.

Watanabe, M. and Kamimura, K. (1971a) Observations on the autogeny of horsefly, Tabanus iyoensis Shiraki. Jap. J. Sanit. Zool. 22, 170-176.

Watanabe, M. and Kamimura, F. (1971b) Susceptibility of females of horsefly, Tabanus iyoensis Shiraki, to several insecticides. Jap. J. Sanit. Zool. 22, 69-73.

Watanabe, M. and Kamimura, K. (1973) Attraction effect of the cylindrical sticky-dry ice trap to the horseflies (Diptera, Tabanidae). Jap. J. Appl. Entomol. Zool. 17, 109-111. (in Japanese)

Wiesenhutter, E. (1975) Research into the relative importance of Tabanidae (Diptera) in mechanical disease transmission. III. The epidemiology of anaplasmosis in a Dar-es-Salaam dairy farm. Trop. Anim. Health Prod. 7, 15-22.

Wilson, B.H. (1968a) Toxicity of selected insecticides against adult striped horseflies in laboratory tests. J. Econ. Entomol. 61, 1764-1765.

Wilson, B.H. (1968b) Reduction of tabanid populations on cattle with sticky traps baited with dry ice. J. Econ. Entomol. 61, 827-829.

Wilson, B.H. and Lieux, M. (1972) Pollen grains in the guts of field-collected tabanids in Louisiana. Ann. Entomol. Soc. Am. 65, 1264-1266.

Wilson, B.H. and Meyer, R.B. (1966) Transmission studies of bovine anaplasmosis with the horseflies, Tabanus fuscicostatus and Tabanus nigrovittatus. Am. J. Vet. Res. 27, 367-369.

Wilson, B.H. and Richardson, C.G. (1969) Tabanid hosts in estuarine and alluvial areas of Louisiana. Ann. Entomol. Soc. Am. 62, 1043-1046.

Wilson, B.H., Tugwell, N.P. and Burns, E.C. (1966) Attraction of tabanids to traps with dry ice under field conditions in Louisiana. J. Med. Entomol. 3, 148-149.

Wright, R.E., Anslow, R.O., Thompson, W.H., DeFoliart, G.R., Seawright, G. and Hanson, R.P. (1970) Isolations of LaCrosse virus of the California group from Tabanidae in Wisconsin. Mosquito News 30, 600-603.

Zumpt, F. (1945) Medical and veterinary importance of horse-flies. S. Afr. Med. J. 23, 359-362. 